
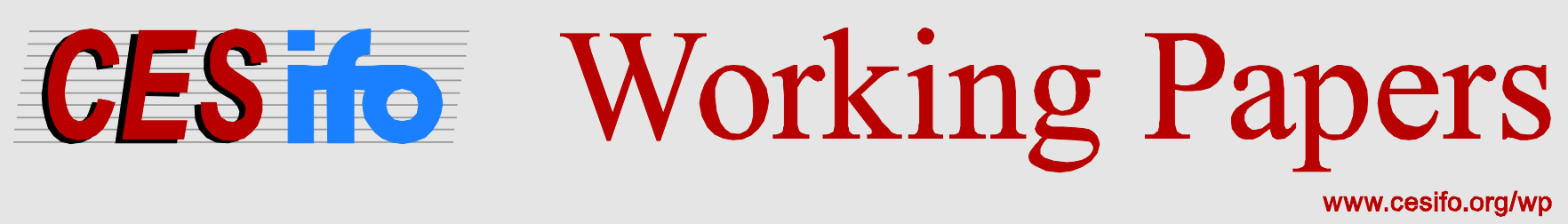

\title{
Inside Post-Socialist Courts: The Determinants of Adjudicatory Outcomes in Slovenian Commercial Disputes
}

\author{
Valentina Dimitrova-Grajzl \\ Peter Grajzl \\ Katarina Zajc
}

CESIFO WORKING PAPER NO. 4894

CATEGORY 1: PUBLIC FINANCE

JULY 2014

An electronic version of the paper may be downloaded

- from the SSRN website:

- from the RePEc website:

- from the CESifo website:

WwW.SSRN.com

www.RePEc.org

www.CESifo-group.org/wp

\section{CESifo}




\title{
Inside Post-Socialist Courts: The Determinants of Adjudicatory Outcomes in Slovenian Commercial Disputes
}

\begin{abstract}
Despite the judiciary's central role in the capitalist market system, micro-level empirical analyses of courts in post-socialist countries are remarkably rare. This paper draws on a unique hand-collected dataset of commercial claims filed at Slovenian courts to examine the determinants of two salient adjudicatory outcomes: whether a case was resolved via trial or settlement and if the case was tried, whether the plaintiff was awarded the initial claim. Consistent with the divergent expectations theory of litigation, we find that trial-based resolution is more likely when the case is complex and less likely when parties use mediation. Addressing sample selection and endogeneity concerns, we show that defendant's legal representation, plaintiff's profitability, and, importantly, court identity are robust predictors of plaintiff victory at trial. Thus, more than two decades after the start of transition in Slovenia, the judicial system is still a source of legal inconsistency and uncertainty.
\end{abstract}

JEL-Code: K400, K410, P370, D020.

Keywords: courts, post-socialist countries, commercial disputes, trial, settlement.

\author{
Valentina Dimitrova-Grajzl \\ Department of Economics and Business \\ Virginia Military Institute \\ USA - Lexington, VA 24450 \\ dimitrova-grajzlvp@vmi.edu
}

\author{
Peter Grajzl* \\ Department of Economics \\ The Williams School \\ Washington \& Lee University \\ USA - Lexington, VA 24450 \\ grajzlp@wlu.edu
}

\author{
Katarina Zajc \\ Faculty of Law \\ University of Ljubljana \\ Slovenia - 1000 Ljubljana \\ katarina.zajc@pf.uni-lj.si
}

*corresponding author

July 4, 2014

We are grateful to Janko Marinko, Sebastijan Potepan, and Nevenka Rihar for assistance in collecting the data and for helpful suggestions. We thank Jaroslaw Beldowski, Kristoffel Grechenig, Sven Hoeppner, Michael Kurschilgen, Maurizio Lisciandra, Alexander Morell, Peter Murrell, Tinni Sen, Eva Schliephake, Erdal Yalcin, seminar participants at the Ifo Institute and the University of Bonn, and participants of the workshop "Economic Analysis of Litigation” held in Catania for valuable comments and discussion. This research was supported by a grant from the CERGE-EI Foundation under the Global Development Network (GDN) program. All opinions expressed are those of the authors and have not been endorsed by CERGE-EI or the GDN. Parts of this research were conducted during Peter Grajzl's research stay at the Center for Economic Studies (CES) in Munich. Peter Grajzl thanks the CES for their hospitality. 


\section{Introduction}

Well-functioning courts are the foundation of an effective legal order and central institutions of a market economy. Courts are the key not only to upholding property rights, but also to promoting large-scale commerce (see, e.g., Johnson et al. 2002, Dixit 2003). In post-socialist and developing countries in particular, empirical evidence indicates that in order for markets to flourish, laws on the books must be backed by adequate enforcement by the courts (Pistor et al. 2000, Skosples 2012).

Despite the widespread agreement about the importance of courts, rigorous micro-level empirical evidence offering insight into their functioning in the post-socialist region is remarkably rare. ${ }^{1}$ With the exception of a handful of studies (see, e.g., Buscaglia and Dakolias 1999, Murrell 2001a, Gadiuta 2012; Dimitrova-Grajzl et al. 2012a, 2012b, 2014), the existing literature is largely limited to descriptive statistics and qualitative analysis (see, e.g., Dietrich 2000, Anderson et al. 2005, Ng et al. 2008). In particular, aside from Kathryn Hendley's insightful analysis of Russian commercial courts (see, e.g. Hendley 2004, 2005), we are aware of no other published empirical studies utilizing case-level court data to shed light on the inner workings of the post-socialist courts of Central and Eastern Europe and the former Soviet Union.

This paper takes a step toward filling this gap in the literature by examining unique caselevel data on commercial claims (i.e. claims between firms and other legal entities) adjudicated in Slovenian courts of first instance. Applied to the Slovenian context, we address questions such as: What predicts trial outcomes? Do disputing parties' characteristics, the type of legal representation, and case specifics matter? When are parties more likely to settle? Does the

\footnotetext{
${ }^{1}$ A related survey-based empirical literature (see, e.g., Hendley et al. 2000, Djankov 2003a, Pyle 2006) provides further evidence about the character and usage of courts in post-socialist countries. Shvets (2013) and LambertMogiliansky et al. (2007) are examples of empirical studies that drawn on data about court quality and activity to study firm behavior in post-socialist countries.
} 
specific venue of adjudication play a role? The determinants of adjudicatory outcomes have long been of interest to scholars of law and economics across different legal systems. ${ }^{2}$ An understanding of the patterns in adjudication within a country's courts is essential for drawing broader lessons about institutional design (see, e.g., Djankov et al. 2003b). The benefits of private litigation as a means of social control of business crucially depend on how court adjudication works in practice; for instance, whether courts apply the law uniformly and whether courts uphold justice rather than favor the powerful. Due to the general "scarcity of data" (Huang et al. 2010a: 789), however, empirical analyses of court-based adjudication are predominantly restricted to the U.S. context (see, e.g., Fournier and Zuehlke 1989, Perloff et al. 1996, Helland and Tabarrok 2002, Bhattacharya et al. 2007).

Slovenia is an interesting and underexplored case for the study of adjudicatory outcomes in courts. A member state of the European Union since 2004, Slovenia has undergone a relatively smooth economic transition. However, more than two decades after gaining independence and abandoning the Yugoslav version of socialism, the country is still struggling with implementing an effective justice system. Court backlogs and delays, as well as judicial corruption, have been a pervasive concern and an obstacle to doing business (see, e.g., Anderson et al. 2005; Zajc 2011).

Our data, drawn from restricted-access court files on commercial disputes, is rich with information about the disputing parties' characteristics and the specifics of each court case. As a consequence, we are able to assess the predictive power of several variables that conceivably shape two salient adjudicatory outcomes: whether a case was resolved via trial or settled; and if tried, whether the plaintiff won the case, that is, was awarded the initial claim. At the micro level, knowledge of the determinants of disputing parties' success at trial is valuable because it

\footnotetext{
${ }^{2}$ For references on the theoretical literature on litigation, see fn. 17.
} 
allows disputing parties and lawyers to, first, form expectations about possible outcomes of disputes (Hadfield 2004) and, second, weigh the relative costs and benefits of different means of resolving disputes (see, e.g., McMillan and Woodruff 1999, Johnson et al. 2002). This, in turn, enhances the predictability of the legal system at the macro level, a valuable institutional attribute (see, e.g., Hayek 1960) usually lacking in post-socialist countries. A sense of consistency of decision-making across courts and whether courts may be susceptible to subversion also clarifies the relative (in)effectiveness of litigation as a means of social control of business. Similarly, an understanding of the determinants of the different modes of case disposition is important since different modes of disposition give rise to different costs. Settlements are completed faster than trials, and consume fewer private and public resources. On the other hand, trials "bring the light of public scrutiny into what would otherwise be the dark corners of...social landscape" (Refo 2004: 4) and thus allow for an opportunity to shape and assert public values (Refo 2004, Fiss 1984, Hadfield 2004).

The central methodological problem in assessing the impact of the various determinants of trial outcomes is the likely endogenous selection of the sample of tried cases (see, e.g., Priest and Klein 1984). To address this issue, we utilize, and combine, standard sample selection estimation methods (see, e.g., Heckman 1979) and the approach of Perloff et al. (1996) which explicitly takes into account that the probability of a trial is a function of the disputing parties' estimated success at trial. A wide range of plaintiff, defendant, and case level controls, as well as court fixed effects, further mitigates the sample selection concerns that may arise from the nonrandom selection of filed cases and the censoring of resolved cases.

Our key findings may be summarized as follows. The likelihood of plaintiff victory at trial is statistically significantly negatively associated with the defendant party's legal 
representation through an attorney or a law firm. In contrast, plaintiff's representation by attorney or law firm does not appear to affect the likelihood of plaintiff victory at trial. These results, which shed light on the value of external legal advice in commercial dispute resolution, are robust to combining the sample selection methods with an instrumental variable approach aimed at isolating the exogenous variation in legal representation status of each disputing party. ${ }^{3}$ We also offer a possible explanation for why in our data the effect of legal representation varies with the identity of the disputing party (i.e. plaintiff versus defendant).

The likelihood of plaintiff victory at trial statistically significantly increases with plaintiff's profitability. In corruption-ridden institutional environments, firm profitability proxies for a firm's willingness or ability to pay bribes (Svensson 2003, Clarke and Xu 2004, Rand and Tarp 2012). While short of being 'hard' evidence of judicial corruption, the positive relationship between the plaintiff's success at trial and the plaintiff's profitability is consistent with the hypothesis that Slovenian courts are susceptible to corruption. Neither the plaintiff's nor the defendant's size, as measured by total assets, or their legal form are statistically significant predictors of plaintiff success at trial. The likelihood of plaintiff victory also does not vary with the complexity of the case and the stakes involved.

In line with the predictions of the divergent expectations theory of litigation (Priest and Klein 1984, Waldfogel 1998), the prospects of a case being resolved via trial rather than settlement are statistically significantly greater for the more complex cases, ceteris paribus. The likelihood of trial, as conjectured, robustly statistically significantly decreases with the disputing parties' exposure to mediation. We also find that, all else equal, settlement is more likely when the plaintiff is a company or a sole trader enterprise rather than a municipality.

\footnotetext{
${ }^{3}$ Hendley et al. (2001) and Waters (2004) illustrate further dimensions of the role of legal profession in the postsocialist world.
} 
Once we control for parties' expectations about trial outcomes, legal representation does not statistically significantly affect the likelihood of trial. The principal-agent theory of the client-lawyer relationship (see Shavell 2004: 435-436) predicts that the effect of legal representation on the mode of case disposition is contingent on the attorney fee arrangement. The lack of a robust effect of legal representation on the mode of case disposition in our data can be reconciled in light of the variety of attorney fee arrangements utilized in Slovenia.

Our paper is relevant to the literature on legal change and reform in post-socialist transition (see, e.g., Hay and Shleifer 1996, Pistor 2000, Murrell 2001b, Kovacic 2001). In contrast to many other post-socialist countries that opted for 'big bang' reforms, Slovenian approach to transition was distinctly slow (see, e.g., Rojec et al. 2004). Yet the resulting Slovenian gradualist approach did not emphasize institution-building, which was an essential aspect of the reform strategy stressed by those taking an evolutionary approach (Murrell 1992). For instance, while the adoption of market-supporting legislation was a high priority at the outset of transition, reform of the ailing court system was not on the early reformers' agenda (see, e.g., Pleskovic and Sachs 1993). This policy perspective resonated with the views that emphasized the importance of law on the books at the expense of investments in legal effectiveness, a perspective later proven to be flawed (see, e.g., Pistor et al. 2000).

A series of court reforms took place only in the mid 2000s, following an external push from the EU. ${ }^{4}$ The impact of reforms, however, has been limited at best (see, e.g., Zajc 2011, Dimitrova-Grajzl et al. 2012a). Our analysis confirms the notion that reform of the judiciary is a difficult endeavor (see, e.g., Botero et al. 2003, Hammergren 2007, Decker et al. 2011). Our results indicate that the prospects of parties' success at trial ceteris paribus vary from court to

\footnotetext{
${ }^{4}$ For example, the 'Lukenda' project, which aimed at increasing the speed of justice, was implemented after a Slovenian citizen Franjo Lukenda filed a lawsuit at the European Court of Human Rights and won the case against the Republic of Slovenia for violation of the right to a hearing within a reasonable time.
} 
court. Moreover, because these jurisdictional effects are large in magnitude, there exist incentives for the litigants to engage in strategic behavior in the choice of adjudication venue, a practice that increases the costs of litigation. Thus, it appears that even more than two decades after the start of transition in Slovenia, the judicial system is still a source of legal inconsistency and uncertainty (see, e.g., Gray and Stiblar 1993). Furthermore, the abovementioned finding that the more profitable plaintiffs on average have more success in court, at the very least, resonates with the ongoing concerns about subversion of justice in Slovenia.

The rest of the paper is organized as follows. Section 2 describes our data. Section 3 outlines our empirical approach. Sections 4 and 5 present and discuss our results on the determinants of adjudicatory outcomes. Section 6 concludes.

\section{Data}

Commercial cases (gospodarske pravdne zadeve) in Slovenia are adjudicated by eleven district courts of first instance. ${ }^{5}$ We focus on commercial claims for compensation of damages (odškodninski spori) as a specific sub-category of commercial disputes tracked by the official Slovenian court statistics. These claims encompass commercial torts (non-contractual disputes) as well as those commercial contractual disputes where the essence of the claim is damage compensation. Our focus on commercial claims for compensation of damages is in part dictated by data collection constraints. In the process of dataset assembly, it was more feasible to preserve the confidential nature of court records in the case of commercial claims for compensation of damages than in the case of other, publicly more notorious, sub-categories of commercial disputes tracked in the court statistics such as, for instance, intellectual property, banking, insurance, unfair competition, and construction industry disputes. At the same time,

\footnotetext{
${ }^{5}$ For an overview of the Slovenian court system, see Dimitrova-Grajzl et al. (2012a, 2012b) and references therein.
} 
disputes leading to claims for compensation of damages occur across industries and businesses and, as such, allow for ample variation in disputing parties' characteristics.

We combine hand-collected, restricted-access, case-level data on commercial claims for compensation of damages disposed in Slovenian courts of first instance during years 2011 and 2012 with publicly available data on basic financial records and the industry of disputing parties provided by the Agency of the Republic of Slovenia for Public Legal Records and Related Services (AJPES). ${ }^{6}$ Based on the official court statistics, there were altogether 446 commercial cases for compensation of damages terminated during years 2011 and 2012. ${ }^{7}$ To be able to focus on the role of plaintiff and defendant characteristics as determinants of adjudicatory outcomes, we first dropped all cases involving multiple plaintiffs or defendants. Following Perloff and Rubinfeld (1988) and Perloff et al. (1996), we further dropped cases disposed via decision on lack of jurisdiction and dismissal on procedural grounds. Of the remaining cases, we dropped cases for which financial and industry classification data are either unavailable or evidently erroneous. We, thus, excluded cases involving individuals, foreign firms, and the government of Republic of Slovenia.

Our final sample, therefore, consists of 191 commercial claims for compensation of damages resolved either via trial-based court judgment or via settlement. We label a case as 'resolved via trial' if court judgment was issued after a completed trial or, alternatively, prior to completed trial by default judgment, via decision on admission, or via the decision of nolle prosequi. We label a case as 'settled' if it was disposed via settlement understood narrowly as an

\footnotetext{
${ }^{6}$ To preserve anonymity of disputing parties, the merging of information from court case files with AJPES data was performed by the court personnel appointed for the project. The identity of disputing parties thus remained unknown to us as researchers.

${ }^{7}$ It is possible that the 446 officially recorded cases is an underestimate of the true volume of commercial cases for compensation of damages adjudicated during this time period. We learned that for record-keeping purposes Slovenian court personnel often sort different types of commercial cases into the category 'Other' when it might be more appropriate to sort them into alternative well-defined categories. Any administrative errors of this type, however, should not affect the representativeness of our sample.
} 
agreement on the outcome of the case signed by the disputing parties in front of a ruling judge, or if a case was withdrawn (adjourned sine die). ${ }^{8} 91$ out of the 191 resolved cases in our sample were resolved via trial. $46 \%$ of resolved cases were filed in 2010, 39\% in year 2011, and 15\% in year 2012. 29\% of cases were resolved in year 2011 and 71\% in year 2012 .

Table 1 presents variable definitions and descriptions. Table 2 provides basic summary statistics. Among the cases resolved via trial, the plaintiff won the case and was awarded the initial claim in $47 \%$ of the cases. The $p$-value for the test that plaintiffs win exactly $50 \%$ of tried cases equals 0.291. Our data are thus broadly consistent with Priest and Klein's (1984) hypothesis of the $50 \%$ plaintiff win rate. ${ }^{9}$

In terms of disputing parties' legal form, $71 \%$ of the plaintiffs and $91 \%$ of the defendants in our sample are companies. $8 \%$ of plaintiffs and the same percent of defendants have the legal status of sole trader enterprises (samostojni podjetnik). $2 \%$ of plaintiffs and an equal percentage of defendants are municipalities. $20 \%$ of cases involve a plaintiff that is a legal entity in public interest (javni zavod). While not reported in Table 1, plaintiffs come from 13 and defendants from 12 distinct industries, where our industry definition follows the national (AJPES) industrial classification. $^{10}$

The average assets size of defendants is nearly three times greater of that of plaintiffs. Defendants are on average also somewhat more profitable (or, rather, less unprofitable given that

\footnotetext{
${ }^{8}$ The proposed categorization of different modes of case disposition into the broad notions of settlement and resolution through trial is consistent with the existing approaches in the empirical literature on modes of case disposition (see, e.g., Galanter 2004, Hadfield 2004).

${ }^{9}$ The $50 \%$ plaintiff win rate hypothesis has been subject to extensive theoretical and empirical scrutiny. For an overview of the literature and references, see Kessler and Rubinfeld (2007: 383-386).

${ }^{10}$ The full list of industries of plaintiffs or defendants is: manufacturing; electricity, gas, steam and air conditioning supply; water supply, sewerage, waste management, and remediation activities; construction; wholesale and retail trade, repair of motor vehicles and motorcycles; transportation and storage; accommodation and food service activities; information and communication; financial and insurance activities; real estate activities; professional, scientific, and technical activities; administrative and support service activities; public administration and defense, compulsory social security; human health and social work activities.
} 
the average profit is negative during the period of our sample) than plaintiffs as measured by the return on assets. The majority of both plaintiffs (74\%) and defendants (58\%) are represented either by an attorney or by a law firm. The remaining plaintiffs and defendants are either selfrepresented or represented by a plenipotentiary (see Section 3.4). Attorneys represent 55\% of the plaintiffs and $37 \%$ of defendants. Law firms represent $19 \%$ of plaintiffs and $21 \%$ of defendants.

The average stakes in the case (the plaintiff's initial claim) equal about EUR 107,100. However, the variability of stakes across cases is large. Court experts were appointed in $7 \%$ of the cases. Court-sponsored mediation was introduced in $19 \%$ of the cases. While not reported in Table 2, among the cases subject to court-sponsored mediation, 14\% were resolved via trial and $86 \%$ were settled.

\section{Empirical Approach}

\subsection{Sample Selection Issues}

The key methodological issues in examination of the determinants of court outcomes stem from the non-random selection of the sample of tried, filed, and disposed cases. We discuss each of these issues in turn below and outline our approach in addressing them. Sections 3.2-3.4 provide details about the implementation of our approach.

Selection of tried cases. The central and in the literature most highlighted problem in assessing the determinants of court outcomes is due to the fact that the sample of tried cases is a very select sample of disputes (Priest and Klein 1984). In particular, the disputing parties' decision to pursue trial rather than settle is likely correlated with unobserved determinants of the parties' success at trial. An ordinary-least-squares (OLS) regression on a sample of tried cases would therefore lead to biased estimates of the determinants of trial outcomes. 
To address this problem of endogenous sample selection, we rely on, and combine, two approaches. We, first, draw on the conventional sample selection estimation methods as developed by Heckman $(1976,1979)$ and by now utilized by a voluminous body of applied social science research. Second, we adopt the approach proposed by Perloff et al. (1996) and applied by Bhattacharya et al. (2007). As we explain in Section 3.3 below, this approach takes into account that the probability of settlement (or, equivalently, trial) is a function of disputing parties' estimated success at trial.

Selection of filed cases. A further layer of endogenous selection may arise because the sample of filed cases need not be a random sample of all disputes (Eisenberg and Farber 1997: S92). In the context of court filings data such as ours, this problem cannot be addressed using the conventional sample selection estimation methods due to the inherent lack of data about the disputes for which a legal claim was never officially asserted (see, e.g., Cooter and Rubinfeld 1989: 1082) ${ }^{11}$ Following Bhattacharya et al. (2007: 628, 643, 652-653), our analysis alleviates this concern via the inclusion of a broad set of plaintiff, defendant, and case level controls, as well as fixed effects (see Section 3.4).

Censoring of tried cases. In an investigation of court outcomes based on cases resolved within a specific time window, the sample is by construction skewed by the censoring of tried cases (see, e.g., Finkelstein et al. 2006). If pending cases systematically differ from resolved cases, an analysis of court outcomes based on resolved cases yields biased results.

We do not possess information about the number or characteristics of tried cases that are as of end of December, 2012, still pending judgment. This precludes us from addressing the censoring problem using recently proposed sample correction techniques (see Finkelstein et al. 2006) or by estimating a richer structural model (see Eisenberg and Farber 1997: S105).

\footnotetext{
${ }^{11}$ Exceptions are studies by Bhattacharya et al. (2007) and Danzon and Lillard (1983).
} 
Furthermore, because the financial indicators and industry data are unavailable to us for the period prior to year 2009, we are unable to restrict the sample to those resolved cases that were filed several years in the past, for which censoring is less problematic. Instead, we follow one of the approaches suggested by Eisenberg and Farber (1997: S103, S107) and control for the year of filing in all of our estimated models.

\subsection{Empirical Model}

We specify the following version of the standard bivariate sample selection model ${ }^{12}$ :

$$
\begin{gathered}
\text { Trial }_{i}=\left\{\begin{array}{cc}
1 & \text { if } w_{i} \gamma+u_{i}>0 \\
0 & \text { if } w_{i} \gamma+u_{i} \leq 0
\end{array}\right. \\
\text { Plaintiff } \operatorname{Win}_{i}=\left\{\begin{array}{cc}
x_{i} \beta+\varepsilon_{i} & \text { if } w_{i} \gamma+u_{i}>0 \\
- & \text { if } w_{i} \gamma+u_{i} \leq 0
\end{array}\right.
\end{gathered}
$$

Expression (1) is the Trial equation or, in the parlance of the sample selection literature, the 'selection equation'. Expression (2) is the Plaintiff Win equation or the 'outcome equation'.

Trial $_{i}$ in (1) is a binary variable that takes on the value 1 if case $i$ was resolved via trial and 0 otherwise (i.e. the case was settled). Plaintiff $W_{i n}$ in (2) is observed only if the case is resolved via trial. When observed, Plaintiff $W_{i n}$ takes on the value 1 if in case $i$ the plaintiff was awarded the initial claim and 0 otherwise. $w_{i}$ and $x_{i}$ are vectors of plaintiff, defendant, and case level explanatory variables, as well as fixed effects, discussed in Section 3.4 below. Importantly, as we elaborate on in Sections 3.3 and 3.4, $x_{i}$ is a subset of $w_{i}$.

We specify the outcome equation (2) as a linear probability model, rather than a probit or a logit, for the following reasons. First, the linear probability model facilitates the use of Heckman's (1979) two-step estimation procedure which yields consistent estimates, relies on

\footnotetext{
${ }^{12}$ This model has also been referred to in the literature as the 'type II Tobit model' (see, e.g., Wooldridge 2002: 562; Cameron and Trivedi 2005: 547).
} 
weaker distributional assumptions than the alternative maximum likelihood-based approaches (Wooldridge 2002: 562; Cameron and Trivedi 2005: 550-551) and, as a further advantage over the maximum likelihood-based estimators, does not suffer from a frequent lack of computational convergence (see, e.g., Wooldridge 2002: 566). ${ }^{13}$ Second, the linear probability model allows us to obtain estimates of the coefficients of either observation-specific or group-invariant dummy variables that cannot be estimated using models that rely on distributional assumptions. ${ }^{14}$ Third, the parameter estimates of the linear probability model are readily interpretable as explanatory variables' marginal effects on the uncensored mean of the outcome of interest.

The error term $u_{i}$ is assumed to be distributed normally with mean zero and variance equal to $1 . u_{i}$ is plausibly correlated with the error term $\varepsilon_{i}$ in (2). The correlation between $u_{i}$ and $\varepsilon_{i}$ gives rise to endogenous sample selection, biasing OLS estimates of $\beta$ based on the sample of tried cases.

\subsection{Estimation Strategy}

To estimate the model in light of the likely endogenous selection of tried cases, we apply Heckman's (1979) two step procedure (the 'Heckit' method). We first estimate a probit of the selection equation to obtain an estimate of $\gamma$. The vector of parameter estimates of the selection equation $\hat{\gamma}$ is of interest on its own since it allows us to discern the factors that influence whether the disputing parties choose to pursue trial rather than settle. For each observation, we then use $\hat{\gamma}$ to compute the estimated inverse Mills ratio $\hat{\lambda}_{i} \equiv \phi\left(w_{i} \hat{\gamma}\right) / \Phi\left(w_{i} \hat{\gamma}\right)$, where $\phi(\cdot)$ and $\Phi(\cdot)$ are respectively the probability density function and the cumulative density function of the

\footnotetext{
${ }^{13}$ We indeed attempted to estimate the sample selection model described by (1) and (2) using a maximum likelihood approach. In addition, we modeled the Plaintiff Win equation as a probit and, accordingly, attempted to estimate a probit model with sample selection (also known as 'double probit'). The maximization of the likelihood function, however, failed to converge in all but a few occasions featuring a very limited set of explanatory variables.

${ }^{14}$ See Anderson $(1987)$ and Caudill $(1987,1988)$ for theory and Johnston and Waldfogel $(2002)$ for an application in the context of court adjudication.
} 
standard normal distribution. In the second stage, we estimate $\beta$ in the outcome equation by running an OLS regression of Plaintiff $\operatorname{Win}_{i}$ on $x_{i}$ and $\hat{\lambda}_{i}$ using the sample of tried cases. We base statistical inference on the appropriately corrected standard errors (see Heckman 1979).

Due to the non-linearity stemming from the inclusion of the inverse Mills ratio among the regressors, the identification of parameters of the outcome equation (2) is formally possible even if the vector of covariates in the outcome equation is identical to the vector of covariates in the selection equation, i.e. if $x_{i}=w_{i}$. Such functional form-based identification, however, can be plagued by severe multicollinearity and, consequently, large standard errors (see, e.g., Wooldridge 2002: 564; Cameron and Trivedi 2005: 551). To obtain more precise parameter estimates, we, therefore, rely on exclusion restrictions: we include in vector $w_{i}$ one or more variables that affect the disputing parties' decision to pursue trial versus settlement, but not the likelihood of plaintiff victory.

Specifically, as an element of the vector $w_{i}$ (but not of the vector $x_{i}$ ) we first include the dummy variable Mediation equal to 1 if in the process of case adjudication the disputing parties were exposed to court-sponsored mediation; and 0 otherwise. Mediation has been utilized in Slovenian courts from the late 1990s. Its usage, however, has been uneven across courts. Since 2010, all district courts are formally obliged to present the disputing parties with a generic offer of court-sponsored mediation. While the decision about whether to pursue mediation ultimately rests with the disputing parties, in practice, the extent of persuasion by courts plays a very significant role. Courts and their presidents vary in their enthusiasm about mediation and the assertiveness with which they steer parties toward mediation. ${ }^{15}$ For instance, while larger courts

\footnotetext{
${ }^{15}$ This is consistent with the "traditional role of the judge in an Austrian-based type of civil procedure", where a civil judge has the authority to undertake an active role in assisting parties to reach settlement throughout the court proceeding (see Galič and Hodges 2012: 202).
} 
have separate offices for alternative dispute resolution, smaller courts do not (Galič and Hodges 2012).

Court-sponsored mediation during case adjudication diminishes the extent of divergence of expectations between the disputing parties about the possible outcome of trial. Exposure to court-sponsored mediation thus increases the prospects of settlement and decreases the prospects of trial. However, once controlling for plaintiff, defendant, and case characteristics as well as court fixed effects, disputing parties' exposure to mediation should not directly affect whether the plaintiff wins the case or not if the case proceeds to trial; that is, the variable Mediation plausibly satisfies the exclusion restriction. We refer to the estimates where Mediation is the only element of vector $w_{i}$ that is at the same time not an element of the vector $x_{i}$ as based on Heckman's (1979) two-step method.

In addition, to address the fact that trial versus settlement decision also depends on disputing parties' expectations of trial outcomes if the case were to go to trial (Priest and Klein 1984), we follow the approach proposed by Perloff et al. (1996) and applied by Bhattacharya et al. (2007). Specifically, we estimate specifications in which $w_{i}$ (but not $x_{i}$ ) further contains the estimated probability of plaintiff victory. The estimated probability of plaintiff victory is a proxy for disputing parties' (common) expectations about the trial outcome. To this end, we first obtain OLS estimates of $\beta$ using the sample of tried cases. Given $\hat{\beta}$, the predicted probability of plaintiff victory equals $\hat{p}_{i} \equiv w_{i} \hat{\beta}$. We refer to thus obtained estimates as based on Heckman's (1979) two-step method combined with the approach of Perloff et al. (1996). ${ }^{16}$

\footnotetext{
${ }^{16}$ Perloff et al. (1996) further control for estimated variance of plaintiff victory as a proxy for parties' attitude toward risk. Following the same strategy does not change our results.
} 


\subsection{Explanatory Variables Common to the Selection Equation and the Outcome Equation}

Finally, we discuss the variables that do not satisfy the exclusion restriction but plausibly affect both the disputing parties' decision to pursue trial and the likelihood of plaintiff victory at trial. These variables are, therefore, the subset of the vector $w_{i}$ that coincides with the vector $x_{i}$.

The choice of explanatory variables discussed below is informed by the theory of litigation and guided by the availability of data. The conceptual framework we rely on is the basic model of litigation as developed by Priest and Klein (1984) ${ }^{17}$ The model predicts that, all else equal, cases proceed to trial rather than settle when the plaintiff is sufficiently more optimistic about the trial outcome than the defendant; litigation expenses are low; and the stakes and settlement costs are high.

Parties' Legal Representation. Expert legal representation improves a party's chance of prevailing at trial (Lederman and Hrung 2006: Sec. I). Legal representation may also shape parties' decision to pursue trial or settle. Lawyer involvement reduces the divergence in parties' expectations about trial outcomes which in turn facilitates settlement. At the same time, the client-lawyer relationship is subject to agency problems, which are in turn influenced by the attorney fees arrangement (Huang 2008, Shavell 2004: Ch. 18, Sec. 7). Hourly fees incentivize lawyers to pursue the relatively longer trial. Flat fees, in contrast, provide an incentive for lawyers to push for the relatively faster settlement. In Slovenia, lawyer fees are subject to a contractual agreement between the disputing party and their legal representative. Both hourly and flat fees are used in practice. The English rule (loser pays principle) applies. The law (Zakon

\footnotetext{
${ }^{17}$ For an overview of the theoretical literature on litigation, see, for example, Cooter and Rubinfeld (1989), Farmer and Pecorino (1996), Hay and Spier (1998), Kaplow and Shavell (2002: Ch.5), and Shavell (2004: Ch. 17-18). Waldfogel (1998) and Farmer and Tiefenthaler (2001) provide further references and empirically test the validity of different theories. Shavell (2004: Ch. 17, Sec. 3.3-3.4) offers a critical discussion of the literature based on asymmetric information and bargaining.
} 
o odvetniški tarifi) specifies the fees to be paid by the losing party relative to the value of a dispute.

The data allow us to distinguish between three distinct legal representation categories for both plaintiffs and defendants. Two of the three-representation by attorney and representation by law firm - involve hiring of legal representation that is 'external' to the disputing party. The third category combines two types of representation: self-representation and representation by a plenipotentiary (pooblaščenec) who is neither an attorney nor a law firm. The law (Zakon o pravdnem postopku) stipulates that for cases adjudicated in district courts, a plenipotentiary must have passed the state examination in law (bar exam). In practice, plenipotentiaries are often retired lawyers, retired judges, and law professors.

We group self-representation and representation by a plenipotentiary under a single category because the coding of the two types of representation is typically confounded in the case files that we drew on to assemble our dataset. For instance, when a company is represented by the head of its own internal legal department, court administrative personnel may choose to classify the party's representation under either of the two categories. In contrast to representation by attorney or law firm, this third legal representation category therefore entails representation that is either 'internal' to the disputing party or involves a qualified legal professional for whom representation of parties in court is not the primary market activity.

We include dummies for plaintiff representation by attorney, plaintiff representation by law firm, defendant representation by attorney, and defendant representation by law firm. The differentiation between representation by attorney and representation by law firm may be empirically relevant since law firms, in contrast to individual attorneys, can rely on specialization and division of labor. This may affect adjudicatory outcomes. The omitted 
category for both plaintiff and defendant representation status is self-representation or representation by a plenipotentiary.

Empirically ascertaining the ceteris paribus effect of legal representation on adjudicatory outcomes in the absence of a true randomized experiment is difficult (see, e.g., Monsma and Lempert 1992, Huang 2008, Huang et al. 2010b). The reason is that the parties' choice of legal representation may be driven by unobservable factors which might at the same time influence adjudicatory outcomes. We address this likely endogeneity of legal representation as follows. First, the richness of our dataset allows us to include a wide set of plaintiff, defendant, and case level controls, as well as court fixed effects (see below). Second, as noted in the previous section, we apply the approach of Perloff et al. (1996) and include the predicted probability of plaintiff victory as an explanatory variable in the Trial equation. This directly addresses the possibility that the choice of legal representation reflects parties' expectations about court outcomes and, at the same time, the decision to pursue litigation. Third, we explore the sensitivity of our results to an instrumental variable approach (discussed in Section 4.1).

Parties' Legal Form. A disputing party's identity may be correlated with parties' litigiousness, which might in turn affect both the decision to assert a legal claim and court outcomes (Eisenberg and Farber 1997). Moreover, courts may be biased toward specific types of plaintiffs either because of idiosyncratic preferences or, in the case of institutionally-deficient legal systems, perhaps even because of differential scope for corruption. We include indicator variables for legal form for each of the disputing parties. Specifically, for both plaintiffs and defendants, we include separate dummies for the following categories of legal form: legal entity in public interest, company, and sole trader enterprise. The omitted category is municipality both in the case of plaintiffs and the defendants. 
Parties' Size and Profitability. Disputing parties' size, as measured by total assets, and profitability, as measured by return-on-assets (ROA), are respectively measures of resource abundance and current economic performance, both of which could affect adjudicatory outcomes. During times of economic downturn, economically underperforming disputing parties may prefer the relatively faster settlement. Courts may favor larger or more profitable parties (see, e.g., Galanter 1974). In corruption-prone institutional environments, firm profitability also proxies for a firm's willingness or ability to pay bribes (Svensson 2003, Clarke and Xu 2004, Rand and Tarp 2012) ${ }^{18}$ Furthermore, resource abundance and profitability likely affect a party's decision on legal representation (Lu et al. 2012: 16). Controlling for firm size and profitability hence also mitigates the omitted variables bias in assessing the effect of legal representation.

Case Characteristics. To control for the specifics of each case, we include the value of stakes involved. The size of the stakes influences the party's decision to pursue trial versus settlement. The direction of the effect, however, is in general ambiguous and depends on the underlying conceptual framework. Holding all else constant, an increase in stakes increases the divergence between the expected gain for the plaintiff and the defendant's expected loss. An increase in stakes thus increases the likelihood of trial (Priest and Klein 1984). However, if greater stakes induce greater trial effort and thus increase litigation costs, an increase in the stakes could reduce the likelihood of trial (see, e.g., Cooter and Rubinfeld 1989). The size of the stakes may also directly influence the outcome of trial. For instance, judges may frown upon exaggerated claims. Finally, controlling for stakes mitigates the omitted variables bias in

\footnotetext{
${ }^{18}$ This is consistent with the 'endogenous harassment' view of corruption (see, e.g., Clarke and Xu 2004). Applied to courts, this theory presumes that judges use observable information such as profitability to gauge disputing parties' willingness-to-pay for a favorable adjudicatory outcome and then demand incentive-compatible bribes which depend on party profitability.
} 
assessing the effect of legal representation: the decision to hire an attorney or a law firm is very likely conditional on the stakes involved.

As a proxy for case complexity, we include a dummy for the involvement of a court expert. The degree of case complexity affects the extent of the divergence of disputing parties' expectations about court verdict and, hence, directly influences parties' incentives to pursue trial versus settlement (Priest and Klein 1984). Depending on judges' expertise and experience with adjudication of specific types of disputes, case complexity may affect court decision at trial. Furthermore, case complexity likely influences parties' decision to seek specialized legal representation.

Fixed Effects. We include a series of fixed effect to control for a number of additional factors affecting both the trial versus settlement decision and the outcome of trial. To control for any period-specific effects on adjudicatory outcomes, we include dummies for the year of filing and the year of case disposition. The inclusion of year dummies enables us to interpret the effect of any monetary variables on the outcomes of interest as real effects. Controlling for the year of filing mitigates sample selection issues due to the censoring of tried cases (see Section 3.1).

We include a full set of plaintiff and defendant industry fixed effects. Industries may vary in their ability to influence judicial decisions. The effect of a disputing party's industry on adjudicatory outcomes might therefore extend beyond the effect of a party's legal form, size, and profitability. Perloff et al. (1996), for example, find that in a sample of antitrust cases filed in U.S. federal district courts, the plaintiff's industry indeed affects the likelihood of plaintiff victory.

Finally, we include a full set of court fixed effects. Court fixed effects control for geographic differences in litigation culture and courts' caseload, as well as any informal court 
norms which can exert a powerful impact on judicial decision-making (see, e.g., Church 1985, Lindquist 2007). The inclusion of court fixed effects does not fully control for judge-specific effects on adjudicatory outcomes. However, as cases filed at a given court are effectively assigned to judges randomly (i.e. alphabetically upon case arrival), our inability to control for judge fixed effects should not confound the impact of the remaining explanatory variables on adjudicatory outcomes.

\section{The Determinants of Plaintiff Victory at Trial}

\subsection{OLS Estimates}

As a benchmark, we first discuss the OLS estimates of the parameters of the Plaintiff Win equation using the sample of tried cases only. Table 3 presents the results. The regression controls for a full set of plaintiff and defendant industry fixed effects, the year of case filing, the year of case disposition, and court fixed effects. Holding all else equal, the likelihood of plaintiff victory is positively but statistically insignificantly associated with plaintiff representation by an attorney or a law firm. The likelihood of plaintiff victory is negatively associated with defendant representation by an attorney or a law firm, although only the effect on defendant representation by attorney is statistically significant. Ceteris paribus, relative to self-representation or representation by a plenipotentiary, defendant representation by an attorney is associated with a 35 percentage point decrease in the likelihood of plaintiff victory.

Based on the estimates in Table 3, neither the plaintiff's nor the defendant's legal form is statistically significantly associated with the likelihood of plaintiff victory at trial. The economic size of the disputing parties, as measured by their respective total assets, is also not a statistically significant predictor of plaintiff victory. The likelihood of plaintiff victory statistically significantly increases with the plaintiff's profitability, as measured by ROA, and decreases, 
albeit statistically insignificantly, with defendant's profitability. The complexity of a case, as proxied by the involvement of court-appointed experts, and the stakes involved are likewise not statistically significantly associated with plaintiff success at trial. Among the various fixed effects, court and defendant industry fixed effects are as a group statistically significant determinants of plaintiff victory of trial (see Table 3).

As discussed earlier, OLS estimates ignore the plausibly endogeneous selection of tried cases. If endogenous sample selection is an issue, the estimates in Table 3 are therefore biased. We next discuss the parameter estimates of the Plaintiff Win equation that explicitly address the likely sample selection problem.

\subsection{Estimates Corrected for Non-Random Selection of Tried Cases}

Table 4 presents the results using Heckman's (1979) two-step method. Table 5 presents the results using the Heckman's (1979) two-step method combined with the approach of Perloff et al. (1996). As in the case of the OLS results presented in Table 3, the specifications in Tables 4 and 5 control for court fixed effects, plaintiff and defendant industry fixed effects, the year of case filing, and the year of case disposition. Here, we focus on the parameter estimates of the Plaintiff Win equation only. (We return to the estimates of the Trial equation below.)

The estimates of the Plaintiff Win equation in Tables 4 and 5 are virtually identical. The coefficient on the estimated inverse Mills ratio is statistically insignificant: $p$-value equals 0.295. Thus, the absence of a sample selection bias cannot be rejected at conventional significance levels. Futhermore, much like the OLS results in Table 3, the estimates in Tables 4 and 5 show that, all else equal, the likelihood of plaintiff victory is statistically significantly negatively associated with defendant representation by attorney and positively but statistically insignificantly associated with plaintiff representation by attorney and by law firm. In contrast to 
the OLS results in Table 3, the results in Tables 4 and 5 indicate that the likelihood of plaintiff victory is statistically significantly negatively associated with defendant representation by a law firm. Relative to self-representation or representation by a plenipotentiary (the omitted category), defendant representation by attorney and defendant representation by law firm ceteris paribus decreases the likelihood of plaintiff victory by about 43 percentage points and 36 percentage points, respectively. The two effects, however, are not statistically significantly different from each other ( $p$-value for the test of the equality of the coefficients equals 0.627 ).

These results suggest that external legal representation improves the chances of defendant, but not plaintiff, success at trial. Under the assumption that the intrinsic motivation and effort of attorneys and law firms does not vary depending on whether they represent a defendant or a plaintiff, a possible explanation for this finding is that in our sample the on average comparatively larger and somewhat more profitable defendants (see Table 2) are able to hire better external legal representation than the on average smaller and less profitable plaintiffs. Hence, the added value of external legal representation is ceteris paribus greater in the case of defendants than in the case of plaintiffs. Despite the wide range of control variables, there is still a possibility that the choice of external legal representation is endogenous to some omitted unobservable factor that we have not been able to adequately account for and, thus, our estimates may be biased. Below, we also explore the robustness of our results on the effect of legal representation to an instrumental variable approach.

With regard to other explanatory variables, the only statistically significant determinant of plaintiff victory is plaintiff's profitability: all else equal, the likelihood of plaintiff victory increases with plaintiff's ROA. This positive association between trial outcome and profitability of a disputing party should of course not be interpreted as 'hard' evidence of judicial corruption. 
However, given that there exists a strong empirical association between willingness to pay bribes and profitability in corruption-ridden environments (see, e.g., Svensson 2003, Clarke and Xu 2004, Rand and Tarp 2012) and ongoing concerns about subversion of justice in Slovenian courts $^{19}$, judicial corruption does provide one possible interpretation of our finding. The lack of a statistically significant association between the likelihood of plaintiff victory at trial and defendant profitability could be explained by any systematic differences between plaintiffs and defendants in our sample as they pertain to the ability of corrupt adjudicators to extract bribes or the willingness of a disputing party to resort to bribery. For instance, because defendants are on average substantially larger than plaintiffs, they may be able to thwart judicial demands for bribes or rely on means other than outright bribery to exert influence on judges.

The plaintiff's and the defendant's legal form, the stakes involved, and the involvement of a court expert as a proxy for case complexity are not statistically significant predictors of plaintiff victory. In contrast, court fixed effects are as a group a statistically significant determinant of plaintiff win rates. This suggests that in Slovenia the venue of adjudication matters for the disputing parties' success at trial. Based on the results in Tables 4 and 5, the likelihood of plaintiff success is all else equal more than 60 percentage points higher in some courts than in others (for brevity, we omit reporting individual coefficients on court dummies). These jurisdictional effects in terms of magnitude notably exceed the ceteris paribus differences in plaintiff success rates across U.S. court districts as estimated by Perloff et al. (1996) using a sample of private antitrust lawsuits.

There are several implications of the finding that holding all else equal plaintiff success rates in Slovenia vary across courts. First, unlike in the U.S., in Slovenia the legislation is

\footnotetext{
${ }^{19}$ According to Transparency International, in 2013, 54\% of respondents in Slovenia felt that judiciary was corrupt or extremely corrupt; see http://www.transparency.org.
} 
uniform across court districts. Thus, jurisdictional effects cannot be attributed to differences in legal rules. Instead, they must reflect differences in the enforcement of legal rules across courts, plausibly due to differences in judicial attitudes toward disputing parties. Second, jurisdictional differences in disputing parties' success rates at trial encourage forum-shopping - strategic behavior by plaintiffs with respect to the choice of adjudication venue - which increases the costs of litigation and is generally viewed as detrimental to the functioning of legal institutions (see, e.g., Clermont and Eisenberg 1995, Moore 2001: Sec III). ${ }^{20}$ Third, the documented jurisdictional effects imply that more than two decades after the start of Slovenian transition, the courts are still a source of legal inconsistency and uncertainty.

Defendant's industry fixed effects are as a group a statistically significant determinant of plaintiff success at trial. In contrast, plaintiff industry fixed effects are not. The contrast in the importance of plaintiff versus defendant industry fixed effects could reflect the differences in the underlying distribution between plaintiffs and defendants across industries in our sample. These differences in firm distribution may capture differences in the degree of ownership-management agency problems between plaintiffs and defendants, with corresponding repercussions for success at trial (see Perloff et al. 1996: 407).

\subsection{Addressing Possible Endogeneity of Legal Representation}

To address the possible endogeneity of legal representation in the Plaintiff Win equation, we explored the sensitivity of our results to an instrumental variable approach. To this end, given the statistically indistinguishable effects of representation by attorney versus representation by law

\footnotetext{
${ }^{20}$ Court jurisdiction for domestic commercial claims of the type we examine is in Slovenia determined as follows. The general rule is that a case should be filed either in the court of the defendant's permanent residence or, alternatively, in the court that has jurisdiction over the geographic area where the act of dispute (a tort or contract breach) had taken place. However, disputing parties may also select any other domestic court of substantive jurisdiction (i.e. district court) as long as the choice is made by consent, signed by both parties, and the request is filed together with the lawsuit (Zakon o pravdnem postopku, Uradni list RS, no. 26/99, articles 46-69).
} 
firm (see above), we first replaced the four legal representation dummy variables reported in Tables 3-5 with two dummy variables: (i) Plaintiff Representation by Attorney or Law Firm and (ii) Defendant Representation by Attorney or Law Firm. Each of these variables takes on the value 1 if the relevant disputing party is represented either by an attorney or a law firm; and 0 otherwise. The reduction of four possibly endogenous legal representation dummies into two reduces the minimum number of required instruments. This is advantageous as the set of suitable candidate instrumental variables in our dataset is limited.

As an instrumental variable for a disputing party's legal representation by attorney or law firm, we used the party's average number of employees in the year prior to filing of the lawsuit. Our rationale for the validity of this instrument is as follows. Holding all else equal, the larger the number of a disputing party's employees, the more likely it is that the disputing party houses its own legal division or personnel legally permitted to represent the party in court. In contrast, the smaller the number of a party's employees, the more likely it is that in the case of a dispute the party must seek legal representation externally, on the attorney market. At the same time, once controlling for a disputing parties' assets and profitability, case complexity, stakes, and court fixed effects, which inter alia control for any court-specific norms of adjudication, the average number of the disputing party's employees is, we argue, unlikely to directly affect the likelihood of plaintiff victory at trial.

The reporting of average number of employees in the AJPES database is overall spottier than the reporting of assets or profits. As a result, the size of our estimated sample of tried cases shrinks to 63 observations. Given the large number of covariates in our model, the associated number of degrees of freedom is very limited. Rather than limiting our analysis to the subsample in which our instruments are non-missing, which leads to efficiency losses, we therefore follow 
Angrist et al. (2010) and Mogstad and Wiswall (2012: Sec. 3.1) and use linear projection to form an instrument set that is defined for a larger sample of observations. Specifically, we replace a subset of the missing values for the average number of employees for each disputing party using fitted values from the linear regression of the party's average number of employees on all exogenous variables. ${ }^{21}$ Under the assumption that the values of instruments are missing randomly, which applies well in our context, the resulting instrumental variables estimator is consistent (Mogstad and Wiswall 2012). ${ }^{22}$

To simultaneously address both endogenous selection of tried cases and endogenous choice of legal representation, we implement a procedure suggested by Wooldridge (2002: 567569). We first run a probit of the Trial equation. As explanatory variables, we use all exogenous variables, including Mediation and the two instruments for plaintiff and attorney legal representation. Using the resulting probit coefficient estimates, we obtain the corresponding inverse Mills ratio. We then estimate a two-stage-least-squares (2SLS) regression which includes the inverse Mills ratio as a regressor and instruments for Plaintiff Representation by Attorney or Law Firm and Defendant Representation by Attorney or Law Firm with Plaintiff Average Number of Employees and Defendant Average Number of Employees, respectively.

Table 6 presents the results. Column (1) presents the benchmark OLS results. Plaintiff victory is statistically significantly negatively associated with defendant's representation by

\footnotetext{
${ }^{21}$ Using only the subsample in which the values of our instruments are non-missing, $\mathrm{R}^{2}$ for the regression of the plaintiff's average number of employees on all exogenous variables equals 0.68 ; $R^{2}$ for the regression of the defendant's average number of employees on all exogenous variables equals 0.46 .

${ }^{22}$ For completeness, we also estimated the two-stage-least squares model with sample selection correction described in this section without relying on imputation (full results are available upon request). The first-stage regression results were strong: Plaintiff Average Number of Employees and Defendant Average Number of Employees were, as conjectured, respectively statistically significantly negatively associated with Plaintiff Representation by Attorney or Law Firm and Defendant Representation by Attorney or Law Firm. In the second-stage regression, the coefficient on Defendant Representation by Attorney or Law Firm was negative (as in our baseline results in Tables 3-5) but statistically insignificant.
} 
attorney or law firm and statistically significantly positively associated with plaintiff's profitability. No other explanatory variable featured in column (1) is statistically significant.

Results in column (2) are based on 2SLS estimation while correcting for the selection of tried cases using Heckman's (1979) two-step method. The qualitative pattern of results is identical to that displayed in the OLS column (1). The only statistically significant explanatory variables featured in column (2) are the dummy for defendant's representation by attorney or law firm (using a one-sided test of significance) and plaintiff's ROA. The signs of the coefficients on these variables match the signs of the corresponding coefficients in the OLS column (1). The implied magnitude of the effect of the defendant's representation by attorney or law firm, however, is larger in column (2), which suggests that addressing the possible endogeneity of legal representation is quantitatively important. The first-stage results (Table A1) confirm our hypothesis: all else equal, the likelihood of a party's representation by attorney or law firm decreases with the party's average number of employees. The effect is highly significant in the case of defendant representation and marginally insignificant (using a one-sided test) in the case of plaintiff representation.

The coefficient on the inverse Mills ratio in column (2) is statistically highly insignificant ( $p$-value equals 0.728 ). We thus fail to reject the null that that the error term in the Plaintiff Win equation is uncorrelated with the error term in the Trial equation. Column (3) presents results based on 2SLS estimation without correcting for sample selection. The resulting coefficient estimates and standard errors are very similar to those reported in column (2). In sum, the instrumental variable results with or without the sample selection correction resonate with the results discussed in Sections 4.1 and 4.2 above. 


\section{The Determinants of Trial versus Settlement}

We next discuss the estimates of the Trial equation reported in Tables 4 and 5 . The corresponding marginal effects are shown in Table 7. The first two columns of Table 7 feature marginal effects based on the estimates reported in Table 4 where the only exclusion restriction is the dummy variable indicating the presence or absence of court-sponsored mediation in the course of case adjudication. The last two columns of Table 7 show marginal effects based on the estimates reported in Table where we further include the estimated probability of plaintiff victory among the exclusion restrictions.

The results in the first two columns of Table 7 suggest that, all else equal, the likelihood that a case proceeds to trial statistically significantly increases with defendant representation by attorney and by law firm. The association between trial and plaintiff representation by attorney and by law firm, respectively, is positive, but not statistically significant. When we further include the estimated probability of plaintiff victory among the exclusion restrictions (last two columns of Table 7), the sign on the marginal effects associated with legal representation dummies remains positive, but the magnitude of marginal effects of the variables for defendant legal representation decreases and, moreover, these marginal effects become statistically insignificant. The contrast between the results on the effect of legal representation in the first versus last two columns of Table 7 is consistent with the interpretation that a disputing party's choice to seek external legal representation by hiring an attorney or a law firm is conditional on the disputing party's expectation about the prospects of trial-based resolution. Thus, once we control for parties' expectation about trial outcome, attorney or law firm representation no longer affects the mode of case resolution. The lack of a robust effect of legal representation on the disputing parties' decision to pursue trial can be reconciled in light of the fact that client-lawyer 
contracts in Slovenia are based on both hourly and flat fees. The usage of a variety of attorney fee arrangements may blur any principal-agent effects in legal representation.

Relative to the case when the plaintiff or respectively the defendant is a municipality, the likelihood of case reaching trial is ceteris paribus lower if the plaintiff or respectively the defendant is either a sole trader enterprise or a company. The likelihood of case reaching trial is ceteris paribus higher if the plaintiff is a legal entity in public interest. One interpretation of this finding is that companies and sole trader enterprises face higher, and legal entities in public interest lower, opportunity costs associated with lengthy case resolution than municipalities. The prospect of trial-based case resolution further statistically significantly decreases with defendant's profitability. This result could reflect the fact that when sued, the in our sample on average less profitable defendants prefer to strategically delay the resolution of the lawsuit and, therefore, prefer to pursue trial.

The likelihood of trial increases with the complexity of the case as proxied by involvement of a court expert, a finding that is consistent with the prediction of the divergent expectations theory of litigation (see, e.g., Priest and Klein 1984, Waldfogel 1998). The theory predicts that settlement is less likely when cases are complex and, hence, parties' expectations more likely divergent. In contrast to the predictions of the theory, however, we do not find an effect of stakes on the parties' decision to pursue trial. The marginal effect of stakes is statistically highly insignificant regardless of the specification ( $p$-value equals 0.586 for the marginal effect based on the estimates in Table 4 and 0.513 for the marginal effect based on the estimates in Table 5).

The likelihood of trial is, as anticipated, negatively associated with parties' exposure to court-sponsored mediation. The effect is highly statistically significantly. In terms of the 
magnitude, holding all else equal, court-sponsored mediation decreases the likelihood of trial by about 39 percentage points. Neither plaintiff nor defendant size as measured by total assets matter for whether a case is resolved via trial or settled. Court fixed effects (coefficients not reported) are as a group a statistically significant predictor of the mode of case disposition (see Tables 4 and 5). In contrast, plaintiff industry fixed effects and defendant industry fixed effects respectively do not robustly statistically significantly predict trial versus settlement.

The estimated probability of plaintiff victory (see last two columns of Table 7) does not statistically significantly predict trial-based case resolution ( $p$-value equals 0.730 ). Following Perloff et al. (1996: 403, 406), the coefficient on the estimated probability of plaintiff victory may be interpreted as capturing the extent of divergence between the total (litigation-related and broader reputational) damages as perceived by the defendant and the award perceived by the plaintiff. $^{23}$ The fact that the coefficient on the estimated probability of plaintiff victory is not statistically significantly different from zero suggests that reputation effects are not a significant factor for defendants. This finding resonates with the results of Perloff et al. (1996) who likewise find that reputation effects are not a significant factor for defendants in private antitrust suits filed in U.S. district courts.

\section{Conclusion}

Using a unique hand-collected dataset and contributing to the sparse literature on the topic, this paper sheds light on the functioning of post-socialist courts by studying the determinants of adjudicatory outcomes in commercial disputes filed at Slovenian courts of first instance. Consistent with the divergent expectations theory of litigation (Priest and Klein 1984, Waldfogel

\footnotetext{
${ }^{23}$ This follows from the fact that the expected gain to both parties from settling rather than pursuing trial (i.e. the difference between the defendant's expected loss from going to trial and the plaintiff's expected gain from trial) depends on the product of two terms: (i) the difference between the defendant's and the plaintiff's subjective estimate of the damages if the plaintiff prevails at trial; and (ii) the parties' estimated probability that the plaintiff prevails at trial. See Perloff et al (1996).
} 
1998), we find that the likelihood of trial-based resolution increases with case complexity and decreases with the usage of court-sponsored mediation. Parties' legal representation, size, profitability, and stakes involved exhibit no robust effect of on the mode of case disposition.

We further find that the prospect of plaintiff victory at trial is predicted by plaintiff's profitability, defendant's legal representation, and court identity. In contrast, the size and legal form of disputing parties, the stakes involved, and case complexity do not predict plaintiff success at trial. The robust positive association between the likelihood of plaintiff success at trial and the plaintiff's profitability should not be interpreted as 'hard' evidence of judicial corruption. However, this result does lend empirical support to ongoing concerns about the courts' susceptibility to subversion by powerful interests and casts doubt on the ability of Slovenian courts to uphold justice. The quantitatively important effect of adjudication venue for parties' success at trial suggests that more than two decades after the start of transition, courts are still a source of legal inconsistency and uncertainty. The documented differences across Slovenian courts in the prospects for parties' success at trial also have repercussions for forum-shopping and the resulting social costs arising from strategic behavior of litigants. Collectively, these results highlight the limitations of private litigation as a means of social control of business (see, e.g., Djankov et al. 2003b) in a post-socialist institutional environment, despite the implementation of a series of reforms aimed at reforming the judiciary (see, e.g., Zajc 2011, Dimitrova-Grajzl et al. 2012a).

Well-functioning courts are critical to doing business in large impersonal markets. Successful reform of a country's system of courts necessitates insight into what actually takes place inside these institutions. In contrast to the analysis of firm-level micro data, scholars of post-socialist and developing countries have thus far devoted very little effort to the collection 
and analysis of court-based micro data. The study of court-level data from emerging market economies constitutes a fruitful avenue for future research. 


\section{References}

Anderson, James, David Bernstein, and Cheryl Gray. 2005. Judicial Systems in Transition Economies: Assessing the Past, Looking to the Future. The World Bank: The International Bank for Reconstruction and Development.

Anderson, G.J. 1987. "Prediction Tests in Limited Dependent Variable Models." Journal of Econometrics, 34:1-2, 253-261.

Angrist, Joshua, Victor Lavy, and Analia Schlosser. 2010. "Multiple Experiments for the Causal Link between the Quantity and Quality of Children." Journal of Labor Economics, 28:4, 773824.

Bhattacharya, Utpal, Neal Galpin, and Bruce Haslem. 2007. "The Home Court Advantage in International Corporate Litigation." Journal of Law and Economics, 50:4, 625-660.

Botero, Juan Carlos, Rafael La Porta, Florencio Lopez-de-Silanes, Andrei Shleifer, and Alexander Volokh. 2003. "Judicial Reform." World Bank Research Observer, 18:1, 61-88.

Buscaglia, Edgardo and Maria Dakolias. 1999. Comparative International Study of Court Performance Indicators: A Descriptive and Analytical Account. The World Bank: The International Bank for Reconstruction and Development.

Cameron, A. Colin and Pravin K. Trivedi. 2005. Microeconometrics, Methods and Applications. Cambridge University Press.

Caudill, Steven B. 1987. "Dichotomous Choice Models and Dummy Variables." Journal of the Royal Statistical Society. Series D (The Statistician), 36:4, 381-383.

Caudill, Steven B. 1988. "An Advantage of the Linear Probability Model over Probit or Logit." Oxford Bulletin of Economics and Statistics, 50:4, 425-427.

Church, Thomas W. Jr. 1985. "Examining Local Legal Culture." Law and Social Inquiry, 10:3, 449-510.

Clarke, George R.G. and Lixin Colin Xu. 2004. "Privatization, Competition, and Corruption: How Characteristics of Bribe Takers and Payers Affect Bribes to Utilities." Journal of Public Economics, 88:9-10, 2067-2097.

Clermont, Kevin M. and Theodore Eisenberg. 1995. "Exorcising the Evil of Forum-Shopping." Cornell Law Review, 80, 1507-1535.

Cooter, Robert D. and Daniel L. Rubinfeld. 1989. "Economic Analysis of Legal Disputes and Their Resolution." Journal of Economic Literature, 27:3, 1067-1097.

Danzon, Patricia M. and Lee A. Lillard. 1983. "Settlement Out of Court: The Disposition of Medical Malpractice Claims." Journal of Legal Studies, 12, 345-377.

Decker, Klaus, Christian Möhlen, and David F. Varela. 2011. Improving the Performance of Justice Institutions: Recent Experiences from Selected OECD Countries Relevant for Latin America. The International Bank for Reconstruction and Development/The World Bank.

Dietrich, Mark. 2000. Legal and Judicial Reform in Central Europe and the Former Soviet Union: Voices from Five Countries. The World Bank: The International Bank for Reconstruction and Development.

Dimitrova-Grajzl, Valentina, Peter Grajzl, and Katarina Zajc. 2014. "Understanding Modes of Civil Case Disposition: Evidence from Slovenian Courts." Forthcoming in Journal of Comparative Economics. Available at: http://dx.doi.org/10.1016/j.jce.2014.04.006. 
Dimitrova-Grajzl, Valentina, Peter Grajzl, Janez Sustersic, and Katarina Zajc. 2012a. "Court Output, Judicial Staffing, and the Demand for Court Services: Evidence from Slovenian Courts of First Instance." International Review of Law and Economics, 32:1, 19-29.

Dimitrova-Grajzl, Valentina, Peter Grajzl, Janez Sustersic, and Katarina Zajc. 2012b. "Judicial Incentives and Performance at Lower Courts: Evidence from Slovenian Judge-Level Data." Review of Law and Economics, 8:1, 215-252.

Dixit, Avinash. 2003. "Trade Expansion and Contract Enforcement." Journal of Political Economy, 111:6, 1293-1317.

Djankov, Simeon, Rafael La Porta, Florencio Lopez-de-Silanes, and Andrei Shleifer. 2003a. "Courts." Quarterly Journal of Economics, 118:2, 453-517.

Djankov, Simeon, Edward L. Glaeser, Rafael La Porta, Florencio Lopez-de-Silanes, and Andrei Shleifer. 2003b. "The New Comparative Economics." Journal of Comparative Economics, 31:4, 595-619.

Eisenberg, Theodore and Henry S. Farber. 1997. "The Litigious Plaintiff Hypothesis: Case Selection and Resolution." RAND Journal of Economics, 28:0, Special Issue in Honor of Richard E. Quandt (1997), S92-S112

Farmer, Amy and Paul Pecorino. 1996. "Issues of Informational Asymmetry in Legal Bargaining." In: Anderson, David A. (Ed.), Dispute Resolution: Bridging the Settlement Gap, JAI Press, 79-105.

Farmer, Amy and Jill Tiefenthaler. 2001. "Conflict in Divorce Disputes: The Determinants of Pretrial Settlement." International Review of Law and Economics, 21, 157-180.

Finkelstein, Michael O., Bruce Levin, Ian W. McKeague, and Wei-Yann Tsai. 2006. "A Note on the Censoring Problem in Empirical Case-Outcome Studies." Journal of Empirical Legal Studies, 3:2, 375-395.

Fiss, Owen M. 1984. "Against Settlement." Yale Law Journal, 93, 1073-1090.

Fournier, Gary M. and Thomas W. Zuehlke. 1989. "Litigation and Settlement: An Empirical Approach." Review of Economics and Statistics, 71:2, 189-195.

Gadiuta, Filip. 2012. "The Romanian Constitutional Court's Relationship with the Ordinary Courts: What Are Some of the Causes of Its High Caseload?" Review of Central and East European Law, 37:1, 53-93.

Galanter, Marc. 1974. "Why the 'Haves' Come Out Ahead: Speculations on the Limits of Legal Change." Law and Society Review, 9:1, 95-160.

Galanter, Marc. 2004. "The Vanishing Trial: An Examination of Trials and Related Matters in Federal and State Courts." Journal of Empirical Legal Studies, 1:3, 459-570.

Galič, Aleš and Christopher Hodges. 2012. "Slovenia." In: Hodges, Christopher, Iris Benöhr, and Naomi Creutzfeld-Banda (Eds.), Consumer ADR in Europe (Civil Justice Systems), Hart Publishing, 197-206.

Gray, Cheryl W. and Franjo D. Stiblar. 1993. "The Evolving Legal Framework for Private Sector Activity in Slovenia." University of Pennsylvania Journal of International Business Law, $14: 2,119-167$.

Hadfield, Gillian K. 2004. "Where Have all the Trials Gone? Settlements, Non-Trial Adjudications and Statistical Artifacts in the Changing Disposition of Federal Civil Cases." Journal of Empirical Legal Studies, 1:3, 705-734. 
Hammergren, Linn. 2007. Envisioning Reform: Conceptual and Practical Obstacles to Improving Judicial Performance in Latin America. Penn State University Press.

Hay, Bruce L. and Kathryn E. Spier. 1998. "Settlement of Litigation." In: The New Palgrave Dictionary of Economics and the Law, Macmillan Reference Limited, 442-451.

Hayek, Friedrich A. 1960. The Constitution of Liberty. University of Chicago Press.

Heckman, James J. 1976. "The Common Structure of Statistical Models of Truncation, Sample Selection and Limited Dependent Variables and a Simple Estimator for Such Models." Annals of Economic and Social Measurement, 5/4, 475-492.

Heckman, James J. 1979. "Sample Selection Bias as a Specification Error." Econometrica, 47:1, 153-161.

Helland, Eric and Alexander Tabarrok. 2002. "The Effect of Electoral Institutions on Tort Awards." American Law and Economics Review, 4:2, 341-370.

Hendley, Kathryn. 2005. "Making Sense of Business Litigation in Russia." In: Sharlet, Robert and Ferdinand Feldbrugge (eds.), Public Policy and Law in Russia, 115-148.

Hendley, Kathryn. 2004. "Business Litigation in Russia: A Portrait of Debt Collection in Russia." Law and Society Review, 31:1, 305-347.

Hendley, Kathryn, Peter Murrell, and Randi Ryterman. 2001. "Agents of Change or Unchanging Agents? The Role of Lawyers within Russian Industrial Enterprises." Law and Social Inquiry, 26:3, 685-715.

Hendley, Kathryn, Peter Murrell, and Randi Ryterman. 2000. "Law, Relationships, and Private Enforcement: Transactional Strategies of Russian Enterprises." Europe-Asia Studies, 52:4, 627-656.

Huang, Kuo-Chang. 2008. "How Legal Representation Affects Case Outcomes: An Empirical Perspective from Taiwan." Journal of Empirical Legal Studies, 5:2, 197-238.

Huang, Kuo-Chang, Kong-Pin Chen, and Chang-Ching Lin. 2010a. "An Empirical Investigation of Settlement and Litigation - The Case of Taiwanese Labor Disputes." Journal of Empirical Legal Studies, 7:4, 786-810.

Huang, Kuo-Chang, Kong-Pin Chen, and Chang-Ching Lin. 2010b. "Does the Type of Criminal Defense Counsel Affect Case Outcomes? A Natural Experiment in Taiwan." International Review of Law and Economics, 30, 113-127.

Johnson, Simon, John McMillan, and Christopher Woodruff. 2002. "Courts and Relational Contracts." Journal of Law, Economics and Organization, 18:1, 221-277.

Johnston, Jason Scott and Joel Waldfogel. 2002. "Does Repeat Play Elicit Cooperation? Evidence from Federal Civil Litigation." Journal of Legal Studies, 31:1, 39-60.

Kaplow, Louis and Steven Shavell. 2002. "Economic Analysis of Law." In: Auerbach, Alan J. and Martin Feldstein (Eds.), Handbook of Public Economics, Vol. III, North Holland, Chapter 25.

Kessler, Daniel P. and Daniel L. Rubinfeld. 2007. "Empirical Study of the Civil Justice System." In: Polinsky, A. Mitchell and Steven Shavell (Eds.), Handbook of Law and Economics, Vol. I, Chapter 5.

Kovacic, William E. 2001. "Institutional Foundations for Economic Legal Reform in Transition Economies: The Case of Competition Policy and Antitrust Enforcement." Chicago-Kent Law Review, 77, 265-315. 
Lambert-Mogiliansky, Ariane, Konstantin Sonin, and Ekaterina Zhuravskaya. 2007. "Are Russian Commercial Courts Biased? Evidence from a Bankruptcy Law Transplant." Journal of Comparative Economics, 35:2, 254-277.

Lederman, Leandra and Warren B. Hrung. 2006. "Do Attorneys Do Their Clients Justice? An Empirical Study of Lawyers' Effects on Tax Court Litigation Outcomes." Wake Forest Law Review, 41, 1235-1295.

Lindquist, Stefanie A. 2007. "Bureaucratization and Balkanization: The Origins and Effects of Decision-Making Norms in the Federal Appellate Courts." University of Richmond Law Review, 41, 659-706.

Lu, Haitan, Hongbo Pan, and Chenying Zhang. 2012. "Property Rights Protection through Litigation: Ownership Bias and the Role of Political Connection." Unpublished manuscript. Available at http://ssrn.com/abstract=2084903.

McMillan, John and Christopher Woodruff. 1999. "Dispute Prevention without Courts in Vietnam." Journal of Law, Economics and Organization, 15:3, 637-658.

Mogstad, Magne and Matthew J. Wiswall. 2012. "Instrumental Variables Estimation with Partially Missing Instruments." Economics Letters, 114, 186-189.

Monsma, Karl and Richard Lempert. 1992. "The Value of Counsel: 20 Years of Representation before a Public Housing Eviction Board." Law and Society Review, 26:3, 627-668.

Moore, Kimberly A. 2001. "Forum Shopping in Patent Cases: Does Geographic Choice Affect Innovation?" North Carolina Law Review, 79, 889-938.

Murrell, Peter. 1992. "Evolution in Economics and in the Economic Reform of the Centrally Planned Economies." In: Clague, Christopher C. and Gordon Rausser (Eds.), The Emergence of Market Economies in Eastern Europe, Blackwell, pp. 35-54.

Murrell, Peter. 2001. Assessing the Value of Law in Transition Economies. University of Michigan Press.

Murrell, Peter. 2001. "Demand and Supply in Romanian Commercial Courts: Generating Information for Institutional Reform." Unpublished manuscript, SSRN Working Paper No. 280428.

Ng, Gar Yein, Marco Velicogna and Cristina Dallara. 2008. "Monitoring and Evaluation of Court System: A Comparative Study." European Commission for the Efficiency of Justice.

Perloff, Jeffrey M. and Daniel L. Rubinfeld. 1988. "Settlements in Private Antitrust Litigation." In: Lawrence J. White (ed.), Private Antitrust Litigation, MIT Press, 149-184.

Perloff, Jeffrey M., Daniel L. Rubinfeld, and Paul Ruud. 1996. "Antitrust Settlements and Trial Outcomes." Review of Economics and Statistics, 78:3, 401-409.

Pistor, Katharina, Martin Raiser, and Stanislaw Gelfer. 2000. "Law and Finance in Transition Economies." Economics of Transition, 8:2, 325-368.

Pistor, Katharina. 2000. "Patterns of Legal Change: Shareholder and Creditor Rights in Transition Economies." European Business Organization Law Review, 1:1, 59-107.

Pleskovic, Boris and Jeffrey D. Sachs. 1994. "Political Independence and Economic Reform in Slovenia." In: Blanchard, Olivier J., Kenneth A. Froot, and Jeffrey D. Sachs (Eds.), The Transition in Eastern Europe, Volume 1, University of Chicago Press, pp. 191-220.

Priest, George L. and Benjamin Kline. 1984. "The Selection of Disputes for Litigation." Journal of Legal Studies, 13:1, 1-55. 
Pyle, William. 2006. "Resolutions, Recoveries and Relationships: The Evolution of Payment Disputes in Central and Eastern Europe." Journal of Comparative Economics, 34:2, 317-337.

Rand, John and Finn Tarp. 2012. "Firm-Level Corruption in Vietnam." Economic Development and Cultural Change, 60:3, 571-595.

Refo, Patricia Lee. 2004. "The Vanishing Trial." Litigation, 30:2, 1-4.

Rojec, Matija, Janez Šušteršič, Boštjan Vasle, Marijana Bednaš, and Slavica Jurančič. 2004. "The Rise and Decline of Gradualism in Slovenia." Post-Communist Economies, 16:4, 459482.

Shavell, Steven. 2004. Foundations of Economic Analysis of Law. Belknap Press/Harvard University Press.

Shvets, Julia. 2013. "Judicial Institutions and Firms' External Finance: Evidence from Russia." Journal of Law, Economics, and Organization, 29:4, 735-764.

Skosples, Goran. 2012. "Law and Credit Constraints in Transition Economies." Economics of Transition, 20:3, 425-455.

Svensson, Jakob. 2003. "Who Must Pay Bribes and How Much? Evidence from a Cross Section of Firms." Quarterly Journal of Economics, 118:1, 207-230.

Waldfogel, Joel. 1998. "Reconciling Asymmetric Information and Divergent Expectations Theories of Litigation." Journal of Law and Economics, 41:2, 451-476.

Waters, Christopher P.W. 2004. Counsel in the Caucasus: Professionalization and Law in Georgia. Brill Academic Publishers.

Wooldridge, Jeffrey M. 2002. Econometric Analysis of Cross Section and Panel Data. MIT Press.

Zajc, Katarina. 2011. "Slovensko sodstvo med leti 1990 in 2011." In: Prunk, Janko and Tomaž Deželan (Eds.), Dvajset let slovenske države. Aristej, pp. 247-262. 
Table 1: Variable Names and Description

\begin{tabular}{|c|c|}
\hline Variable Name & Description \\
\hline Trial & $\begin{array}{l}\text { Dummy equal to } 1 \text { if case was disposed through trial either by court judgment following completion of trial or prior to } \\
\text { completion of trial by judgment on admission, judgment of nolle prosequi, or default judgment. }\end{array}$ \\
\hline Plaintiff Win & Dummy equal to 1 if court judgment awarded the plaintiff their initial claim. \\
\hline Plaintiff Representation Attorney & Dummy equal to 1 if plaintiff is represented by an individual attorney. \\
\hline Plaintiff Representation Law Firm & Dummy equal to 1 if plaintiff is represented by a law firm. \\
\hline Defendant Representation Attorney & Dummy equal to 1 if defendant is represented by an individual attorney. \\
\hline Defendant Representation Law Firm & Dummy equal to 1 if defendant is represented by a law firm. \\
\hline Plaintiff Assets & Plaintiff's assets measured at the end of the last year prior to filing of the lawsuit, in EUR 100 million. \\
\hline Defendant Assets & Defendant's assets measured at the end of the last year prior to filing of the lawsuit, in EUR 100 million. \\
\hline Plaintiff ROA & $\begin{array}{l}\text { Plaintiff's return on assets as the ratio of profit earned in the year prior to filing of the lawsuit and total assets } \\
\text { measured at the end of the last year prior to filing of the lawsuit }\end{array}$ \\
\hline Defendant ROA & $\begin{array}{l}\text { Defendant's return on assets as the ratio of profit earned in the year prior to filing of the lawsuit and total assets } \\
\text { measured at the end of the last year prior to filing of the lawsuit. }\end{array}$ \\
\hline Plaintiff Legal Entity in Public Interest & Dummy equal to 1 if plaintiff is a legal entity in public interest (javni zavod). \\
\hline Plaintiff Company & Dummy equal to 1 if plaintiff is a company (gospodarska družba). \\
\hline Plaintiff Sole Trader Enterprise & Dummy equal to 1 if plaintiff is a sole trader enterprise (samostojni podjetnik). \\
\hline Plaintiff Municipality & Dummy equal to 1 if plaintiff is a municipality (lokalna skupnost). \\
\hline Defendant Company & Dummy equal to 1 if defendant is a company (gospodarska družba). \\
\hline Defendant Sole Trader Enterprise & Dummy equal to 1 if defendant is a sole trader enterprise (samostojni podjetnik). \\
\hline Defendant Municipality & Dummy equal to 1 if defendant is a municipality (lokalna skupnost). \\
\hline Stakes & Plaintiff's initial claim as stipulated in the lawsuit, in EUR $100,000$. \\
\hline Court Expert & Dummy equal to 1 if court expert was involved in adjudication of the case. \\
\hline Mediation & Dummy equal to 1 if court-sponsored mediation was introduced in the process of case adjudication. \\
\hline Plaintiff Average Number of Employees & Plaintiff's average number of employees in the last year prior to filing of the lawsuit. \\
\hline Defendant Average Number of Employees & Defendant's average number of employees in the last year prior to filing of the lawsuit. \\
\hline
\end{tabular}


Table 2: Summary Statistics

\begin{tabular}{lccccc}
\hline \hline Variable Name & No. Obs. & Mean & Std. Dev. & Min. & Max. \\
\hline Trial & 191 & 0.476 & 0.501 & 0 & 1 \\
Plaintiff Win & 91 & 0.473 & 0.502 & 0 & 1 \\
Plaintiff Representation Attorney & 191 & 0.550 & 0.499 & 0 & 1 \\
Plaintiff Representation Law Firm & 191 & 0.188 & 0.392 & 0 & 1 \\
Defendant Representation Attorney & 191 & 0.366 & 0.483 & 0 & 1 \\
Defendant Representation Law Firm & 191 & 0.215 & 0.412 & 0 & 1 \\
Plaintiff Legal Entity in Public Interest & 191 & 0.199 & 0.400 & 0 & 1 \\
Plaintiff Company & 191 & 0.707 & 0.456 & 0 & 1 \\
Plaintiff Sole Trader Enterprise & 191 & 0.079 & 0.270 & 0 & 1 \\
Plaintiff Municipality & 191 & 0.016 & 0.125 & 0 & 1 \\
Defendant Company & 191 & 0.906 & 0.293 & 0 & 1 \\
Defendant Sole Trader Enterprise & 191 & 0.079 & 0.270 & 0 & 0 \\
Defendant Municipality & 191 & 0.016 & 0.125 & 0 & 1 \\
Plaintiff Assets (in EUR 100 million) & 191 & 1.399 & 3.707 & 0.00007 & 1 \\
Defendant Assets (in EUR 100 million) & 191 & 4.067 & 8.387 & 0.00017 & 25.565 \\
Plaintiff ROA & 191 & -0.038 & 0.135 & -0.972 & 55.291 \\
Defendant ROA & 191 & -0.003 & 0.111 & -1.046 & 0.252 \\
Stakes (in EUR 100,000) & 191 & 1.071 & 4.247 & 0.041 & 0.303 \\
Court Expert & 191 & 0.073 & 0.261 & 0 & 53.207 \\
Mediation & 191 & 0.188 & 0.392 & 0 & 1 \\
Plaintiff Average Number of Employees & 177 & 279.4 & 477.2 & 0 & 1 \\
Defendant Average Number of Employees & 167 & 429.2 & 1106.0 & & 0 \\
\hline \hline Notes: See Table 1 for variable description & & & & 3408 \\
\end{tabular}


Table 3: Regression Results, Plaintiff Win Equation, OLS

\begin{tabular}{|c|c|c|}
\hline \multirow[b]{2}{*}{ Explanatory Variables } & \multicolumn{2}{|c|}{ Plaintiff Win Equation } \\
\hline & Coefficient & Standard Error \\
\hline \multicolumn{3}{|l|}{ Parties' Legal Representation } \\
\hline Plaintiff Representation Attorney & 0.021 & $(0.261)$ \\
\hline Plaintiff Representation Law Firm & 0.101 & $(0.322)$ \\
\hline Defendant Representation Attorney & $-0.349 * *$ & $(0.166)$ \\
\hline Defendant Representation Law Firm & -0.312 & $(0.278)$ \\
\hline \multicolumn{3}{|l|}{ Parties' Legal Form } \\
\hline Plaintiff Legal Entity in Public Interest & 0.406 & $(0.712)$ \\
\hline Plaintiff Company & -0.222 & $(0.493)$ \\
\hline Plaintiff Sole Trader Enterprise & -0.175 & (0.519) \\
\hline Defendant Company & 0.862 & $(0.753)$ \\
\hline Defendant Sole Trader Enterprise & 1.069 & $(0.777)$ \\
\hline \multicolumn{3}{|l|}{ Parties' Size and Profitability } \\
\hline Plaintiff Assets (in EUR 100 million) & -0.012 & $(0.023)$ \\
\hline Defendant Assets (in EUR 100 million) & 0.001 & $(0.009)$ \\
\hline Plaintiff ROA & $1.200 * *$ & $(0.578)$ \\
\hline Defendant ROA & -0.127 & $(0.492)$ \\
\hline \multicolumn{3}{|l|}{ Case Characteristics } \\
\hline Stakes (in EUR 100,000) & -0.007 & $(0.037)$ \\
\hline Court Expert & -0.039 & $(0.228)$ \\
\hline \multicolumn{3}{|l|}{ Fixed Effects } \\
\hline Court FEs & \multicolumn{2}{|c|}{ Yes $[p=0.082]$} \\
\hline Plaintiff Industry FEs & \multicolumn{2}{|c|}{ Yes $[p=0.159]$} \\
\hline Defendant Industry FEs & \multicolumn{2}{|c|}{ Yes $[p=0.080]$} \\
\hline Filing Year FEs & \multicolumn{2}{|c|}{ Yes $[p=0.158]$} \\
\hline Disposition Year FEs & \multicolumn{2}{|c|}{ Yes $[p=0.410]$} \\
\hline R-squared & \multicolumn{2}{|c|}{0.5951} \\
\hline No. Obs. & \multicolumn{2}{|c|}{91} \\
\hline \multicolumn{3}{|c|}{$\begin{array}{l}\text { Notes: Results based on OLS regression. For both plaintiff's and defendant's legal form } \\
\text { respectively, the omitted category is municipality. For both plaintiff's and defendant's } \\
\text { legal representation respectively, the omitted category is self-represented or } \\
\text { represented by court-approved plenipotentiary. Reported standard errors are } \\
\text { heteroskedasticity-robust. *, **, and *** indicate significance at the } 10 \%, 5 \% \text {, and } 1 \% \\
\text { levels, respectively. The reported } p \text {-values for the groups of fixed effects are for the } \\
F \text {-test of joint significance. }\end{array}$} \\
\hline
\end{tabular}


Table 4: Regression Results, Heckman (1979) Two-Step Method

\begin{tabular}{|c|c|c|c|c|}
\hline \multirow[b]{2}{*}{ Explanatory Variables } & \multicolumn{2}{|c|}{ Plaintiff Win Equation } & \multicolumn{2}{|c|}{ Trial Equation } \\
\hline & Coefficient & Standard Error & Coefficient & Standard Error \\
\hline \multicolumn{5}{|l|}{ Parties' Legal Representation } \\
\hline Plaintiff Representation Attorney & 0.026 & $(0.249)$ & 0.545 & $(0.509)$ \\
\hline Plaintiff Representation Law Firm & 0.096 & $(0.272)$ & 0.371 & $(0.574)$ \\
\hline Defendant Representation Attorney & $-0.426 * * *$ & $(0.151)$ & $1.221 * * *$ & $(0.436)$ \\
\hline Defendant Representation Law Firm & $-0.357^{* *}$ & $(0.183)$ & $1.174 * *$ & $(0.466)$ \\
\hline \multicolumn{5}{|l|}{ Parties' Legal Form } \\
\hline Plaintiff Legal Entity in Public Interest & 0.663 & $(0.830)$ & 1.539 & $(1.141)$ \\
\hline Plaintiff Company & 0.062 & $(0.661)$ & $-2.368 *$ & $(1.394)$ \\
\hline Plaintiff Sole Trader Enterprise & 0.154 & $(0.691)$ & $-3.100 * *$ & $(1.513)$ \\
\hline Defendant Company & 0.590 & $(0.806)$ & $-4.771^{* * *}$ & $(1.253)$ \\
\hline Defendant Sole Trader Enterprise & 0.765 & $(0.825)$ & $-4.673^{* * *}$ & $(1.356)$ \\
\hline \multicolumn{5}{|l|}{ Parties' Size and Profitability } \\
\hline Plaintiff Assets (in EUR 100 million) & -0.008 & $(0.015)$ & 0.022 & $(0.037)$ \\
\hline Defendant Assets (in EUR 100 million) & -0.000 & $(0.006)$ & 0.023 & $(0.025)$ \\
\hline Plaintiff ROA & $1.125^{* *}$ & $(0.434)$ & 0.771 & $(1.050)$ \\
\hline Defendant ROA & 0.103 & $(0.449)$ & $-4.964 * *$ & $(2.208)$ \\
\hline \multicolumn{5}{|l|}{ Case Characteristics } \\
\hline Stakes (in EUR 100,000) & -0.006 & $(0.025)$ & -0.019 & $(0.035)$ \\
\hline Court Expert & -0.128 & $(0.181)$ & $0.970^{*}$ & $(0.533)$ \\
\hline \multicolumn{5}{|l|}{ Fixed Effects } \\
\hline Court FEs & \multicolumn{2}{|c|}{ Yes $[p=0.004]$} & \multicolumn{2}{|c|}{ Yes $[p=0.096]$} \\
\hline Plaintiff Industry FEs & \multicolumn{2}{|c|}{ Yes $[p=0.343]$} & \multicolumn{2}{|c|}{ Yes $[p=0.484]$} \\
\hline Defendant Industry FEs & \multicolumn{2}{|c|}{ Yes $[p=0.022]$} & \multicolumn{2}{|c|}{ Yes [ $p=1.101]$} \\
\hline Filing Year FEs & \multicolumn{2}{|c|}{ Yes $[p=0.007]$} & \multicolumn{2}{|c|}{ Yes $[p=0.309]$} \\
\hline Disposition Year FEs & \multicolumn{2}{|c|}{ Yes $[p=0.352]$} & \multicolumn{2}{|c|}{ Yes $[p=0.154]$} \\
\hline \multicolumn{5}{|l|}{ Exclusion Restriction } \\
\hline Mediation & & & $-1.701 * * *$ & $(0.501)$ \\
\hline \multicolumn{5}{|l|}{ Inverse Mills Ratio } \\
\hline Lambda-hat & -0.200 & $(0.191)$ & & \\
\hline \multicolumn{5}{|c|}{$\begin{array}{l}\text { Notes: Results based on Heckman (1979) two-step estimation method. Total number of observations is } 191 \text { and the number o } \\
\text { uncensored observations is } 91 \text {. For both plaintiff's and defendant's legal form respectively, the omitted category is municipality. Fo } \\
\text { both plaintiff's and defendant's legal representation respectively, the omitted category is self-represented or represented by a court } \\
\text { approved plenipotentiary. Reported standard errors are heteroskedasticity-robust. *, } * * \text {, and } * * * \text { indicate significance at the } 10 \% \\
5 \% \text {, and } 1 \% \text { levels, respectively. The reported } p \text {-values for the groups of fixed effects are for the Chi-Square test of join } \\
\text { significance. }\end{array}$} \\
\hline
\end{tabular}


Table 5: Regression Results,

Heckman (1979) Two-Step Method Combined with the Approach of Perloff et al. (1996)

\begin{tabular}{|c|c|c|c|c|}
\hline \multirow[b]{2}{*}{ Explanatory Variables } & \multicolumn{2}{|c|}{ Plaintiff Win Equation } & \multicolumn{2}{|c|}{ Trial Equation } \\
\hline & Coefficient & Standard Error & Coefficient & Standard Error \\
\hline \multicolumn{5}{|l|}{ Parties' Legal Representation } \\
\hline Plaintiff Representation Attorney & 0.026 & $(0.249)$ & 0.563 & $(0.515)$ \\
\hline Plaintiff Representation Law Firm & 0.096 & $(0.272)$ & 0.459 & $(0.643)$ \\
\hline Defendant Representation Attorney & $-0.426 * * *$ & $(0.151)$ & 0.914 & $(1.065)$ \\
\hline Defendant Representation Law Firm & $-0.357 * *$ & $(0.182)$ & 0.899 & $(0.986)$ \\
\hline \multicolumn{5}{|l|}{ Parties' Legal Form } \\
\hline Plaintiff Legal Entity in Public Interest & 0.663 & $(0.830)$ & 1.711 & $(1.362)$ \\
\hline Plaintiff Company & 0.062 & $(0.661)$ & $-2.563 *$ & (1.559) \\
\hline Plaintiff Sole Trader Enterprise & 0.154 & $(0.691)$ & $-3.254 * *$ & $(1.635)$ \\
\hline Defendant Company & 0.590 & $(0.806)$ & $-3.968 * * *$ & $(0.766)$ \\
\hline Defendant Sole Trader Enterprise & 0.765 & $(0.825)$ & $-3.687 * * *$ & $(1.478)$ \\
\hline \multicolumn{5}{|l|}{ Parties' Size and Profitability } \\
\hline Plaintiff Assets (in EUR 100 million) & -0.008 & $(0.015)$ & 0.012 & $(0.046)$ \\
\hline Defendant Assets (in EUR 100 million) & -0.000 & $(0.006)$ & 0.024 & $(0.025)$ \\
\hline Plaintiff ROA & $1.125^{* *}$ & $(0.434)$ & 1.829 & $(3.368)$ \\
\hline Defendant ROA & 0.103 & $(0.449)$ & $-5.077^{* *}$ & (2.203) \\
\hline \multicolumn{5}{|l|}{ Case Characteristics } \\
\hline Stakes (in EUR 100,000) & -0.006 & $(0.025)$ & -0.025 & $(0.039)$ \\
\hline Court Expert & -0.128 & $(0.181)$ & $0.935 *$ & $(0.560)$ \\
\hline \multicolumn{5}{|l|}{ Fixed Effects } \\
\hline Court FEs & \multicolumn{2}{|c|}{ Yes $[p=0.004]$} & \multicolumn{2}{|c|}{ Yes $[p<0.001]$} \\
\hline Plaintiff Industry FEs & \multicolumn{2}{|c|}{ Yes $[p=0.343]$} & \multicolumn{2}{|c|}{ Yes $[p=0.599]$} \\
\hline Defendant Industry FEs & \multicolumn{2}{|c|}{ Yes $[p=0.022]$} & \multicolumn{2}{|c|}{ Yes $[p<0.001]$} \\
\hline Filing Year FEs & \multicolumn{2}{|c|}{ Yes $[p=0.007]$} & \multicolumn{2}{|c|}{ Yes $[p=0.776]$} \\
\hline Disposition Year FEs & \multicolumn{2}{|c|}{ Yes $[p=0.352]$} & \multicolumn{2}{|c|}{ Yes $[p=0.161]$} \\
\hline \multicolumn{5}{|l|}{ Exclusion Restrictions } \\
\hline Mediation & & & $-1.701 * * *$ & $(0.501)$ \\
\hline Estimated prob. of plaintiff victory & & & -0.882 & (2.556) \\
\hline \multicolumn{5}{|l|}{ Inverse Mills Ratio } \\
\hline Lambda-hat & -0.200 & $(0.191)$ & & \\
\hline
\end{tabular}


Table 6: Robustness Checks, Plaintiff Win Equation

\begin{tabular}{|c|c|c|c|c|c|c|}
\hline \multirow[b]{2}{*}{ Explanatory Variables } & \multicolumn{2}{|c|}{ (1) OLS } & \multicolumn{2}{|c|}{ (2) 2SLS with Heckit } & \multicolumn{2}{|c|}{ (3) 2SLS } \\
\hline & Coeff. & Std. Error & Coeff. & Std. Error & Coeff. & Std. Error \\
\hline \multicolumn{7}{|l|}{ Parties' Legal Representation } \\
\hline Plaintiff Representation Attorney or Law Firm & 0.023 & $(0.258)$ & -0.514 & $(0.725)$ & -0.471 & $(0.671)$ \\
\hline Defendant Representation Attorney or Law Firm & $-0.357 * *$ & $(0.171)$ & $-0.620 \dagger$ & $(0.426)$ & $-0.657 \dagger$ & $(0.425)$ \\
\hline \multicolumn{7}{|l|}{ Parties' Size and Profitability } \\
\hline Plaintiff Assets (in EUR 100 million) & -0.011 & $(0.022)$ & -0.018 & $(0.015)$ & -0.017 & $(0.015)$ \\
\hline Defendant Assets (in EUR 100 million) & 0.002 & $(0.009)$ & 0.003 & $(0.007)$ & 0.002 & $(0.007)$ \\
\hline Plaintiff ROA & $1.209 * *$ & $(0.558)$ & $1.391 * * *$ & $(0.486)$ & $1.382^{* * *}$ & $(0.493)$ \\
\hline Defendant ROA & -0.144 & $(0.466)$ & -0.760 & $(0.838)$ & -0.596 & $(0.578)$ \\
\hline \multicolumn{7}{|l|}{ Case Characteristics } \\
\hline Stakes (in EUR 100,000) & -0.003 & $(0.034)$ & 0.013 & $(0.028)$ & 0.016 & $(0.029)$ \\
\hline Court Expert & -0.053 & $(0.220)$ & -0.079 & $(0.219)$ & -0.124 & $(0.202)$ \\
\hline \multicolumn{7}{|l|}{ Fixed Effects } \\
\hline Court FEs & \multicolumn{2}{|c|}{ Yes $[p=0.059]$} & \multicolumn{2}{|c|}{ Yes $[p<0.001]$} & \multicolumn{2}{|c|}{ Yes $[p<0.001]$} \\
\hline Plaintiff Legal Form FEs & \multicolumn{2}{|c|}{ Yes $[p=0.409]$} & \multicolumn{2}{|c|}{ Yes $[p=0.159]$} & \multicolumn{2}{|c|}{ Yes $[p=0.130]$} \\
\hline Defendant Legal Form FEs & \multicolumn{2}{|c|}{ Yes $[p=0.271]$} & \multicolumn{2}{|c|}{ Yes $[p=0.179]$} & \multicolumn{2}{|c|}{ Yes $[p=0.100]$} \\
\hline Plaintiff Industry FEs & \multicolumn{2}{|c|}{ Yes $[p=0.071]$} & \multicolumn{2}{|c|}{ Yes $[p=0.029]$} & \multicolumn{2}{|c|}{ Yes $[p=0.013]$} \\
\hline Defendant Industry FEs & \multicolumn{2}{|c|}{ Yes $[p=0.043]$} & \multicolumn{2}{|c|}{ Yes $[p<0.001]$} & \multicolumn{2}{|c|}{ Yes $[p<0.001]$} \\
\hline Filing Year FEs & \multicolumn{2}{|c|}{ Yes $[p=0.127]$} & \multicolumn{2}{|c|}{ Yes $[p=0.023]$} & \multicolumn{2}{|c|}{ Yes $[p=0.024]$} \\
\hline Disposition Year FEs & \multicolumn{2}{|c|}{ Yes $[p=0.426]$} & \multicolumn{2}{|c|}{ Yes $[p=0.311]$} & \multicolumn{2}{|c|}{ Yes $[p=0.335]$} \\
\hline \multicolumn{7}{|l|}{ Inverse Mills Ratio } \\
\hline Lambda-hat & & & 0.110 & $(0.315)$ & & \\
\hline \multicolumn{7}{|c|}{$\begin{array}{l}\text { Notes: Robustness checks. For regressions in all four columns, the dependent variable is Plaintiff Win. Column (1) is based on OLS. Column (2) } \\
\text { is based on 2SLS with Heckman (1979) sample selection correction (two-step method). Column (3) is based on 2SLS without sample correction. } \\
\text { For the regressions in columns (2) and (3), the instruments for the variables Plaintiff Representation Attorney or Law Firm and Defendant } \\
\text { Representation Attorney or Law Firm are Plaintiff Average Number of Employees and Defendant Average Number of Employees; results of the } \\
\text { first-stage regressions for the regression in column (2) are presented in Table A1 in the Appendix. Results in column (2) use Mediation as the } \\
\text { only exclusion restriction in implementing the Heckman (1979) two-step method. For regressions in columns (1) and (3), the number of } \\
\text { observations equals } 90 \text {. For regression in column }(2) \text {, the number of uncensored observations equals } 90 \text {. Reported standard errors are } \\
\text { heteroskedasticity-robust. *, **, and *** indicate significance at the } 10 \%, 5 \% \text {, and } 1 \% \text { levels, respectively. } \dagger \text { indicates significance at the } 10 \% \\
\text { level for a one-sided test. The reported } p \text {-values for the groups of fixed effects are for either the F-test or the Chi-Square test of joint } \\
\text { significance. }\end{array}$} \\
\hline
\end{tabular}


Table 7: Trial Equation, Marginal Effects

\begin{tabular}{|c|c|c|c|c|}
\hline \multirow[b]{2}{*}{ Explanatory Variables } & \multicolumn{2}{|c|}{ Based on estimates in Table 4} & \multicolumn{2}{|c|}{ Based on estimates in Table 5} \\
\hline & Marginal Effect & Standard Error & Marginal Effect & Standard Error \\
\hline \multicolumn{5}{|l|}{ Parties' Legal Representation } \\
\hline Plaintiff Representation Attorney & 0.126 & $(0.117)$ & 0.130 & $(0.118)$ \\
\hline Plaintiff Representation Law Firm & 0.086 & $(0.133)$ & 0.106 & $(0.148)$ \\
\hline Defendant Representation Attorney & $0.282 * * *$ & $(0.094)$ & 0.211 & $(0.244)$ \\
\hline Defendant Representation Law Firm & $0.271 * * *$ & $(0.102)$ & 0.208 & $(0.226)$ \\
\hline \multicolumn{5}{|l|}{ Parties' Legal Form } \\
\hline Plaintiff Legal Entity in Public Interest & $0.326 * * *$ & $(0.027)$ & 0.396 & $(0.319)$ \\
\hline Plaintiff Company & $-0.548 *$ & $(0.314)$ & $-0.593 *$ & $(0.352)$ \\
\hline Plaintiff Sole Trader Enterprise & $-0.717 * *$ & $(0.337)$ & $-0.752^{* *}$ & $(0.365)$ \\
\hline Defendant Company & $-1.103^{* * *}$ & $(0.308)$ & $-0.928 * * *$ & $(0.188)$ \\
\hline Defendant Sole Trader Enterprise & $-1.081 * * *$ & $(0.331)$ & $-0.863 * * *$ & $(0.070)$ \\
\hline \multicolumn{5}{|l|}{ Parties' Size and Profitability } \\
\hline Plaintiff Assets (in EUR 100 million) & 0.005 & $(0.009)$ & 0.003 & $(0.011)$ \\
\hline Defendant Assets (in EUR 100 million) & 0.005 & $(0.006)$ & 0.006 & $(0.006)$ \\
\hline Plaintiff ROA & 0.178 & $(0.242)$ & 0.423 & $(0.777)$ \\
\hline Defendant ROA & $-1.148 * *$ & $(0.488)$ & $-1.174^{* *}$ & $(0.486)$ \\
\hline \multicolumn{5}{|l|}{ Case Characteristics } \\
\hline Stakes (in EUR 100,000) & -0.004 & $(0.008)$ & -0.006 & $(0.009)$ \\
\hline Court Expert & $0.224 *$ & $(0.120)$ & $0.216^{*}$ & $(0.126)$ \\
\hline \multicolumn{5}{|l|}{ Exclusion Restrictions } \\
\hline Mediation & $-0.393 * * *$ & $(0.105)$ & $-0.393 * * *$ & $(0.105)$ \\
\hline Estimated prob. of plaintiff victory & & & -0.204 & $(0.590)$ \\
\hline
\end{tabular}

Notes: Average marginal effects, and their standard errors, of explanatory variables for the Trial equation. The results in the first two columns are based on the estimates in Table 4. The results in the last two columns are based on the estimates in Table 5. *, **, and $* * *$ indicate significance at the $10 \%, 5 \%$, and $1 \%$ levels, respectively. 


\section{Appendix}

Table A1: First-Stage Regressions for 2SLS Estimates of Plaintiff Win Equation Reported in Table 6, Column (2)

\begin{tabular}{|c|c|c|c|c|}
\hline \multirow[b]{2}{*}{ Explanatory Variables } & \multicolumn{2}{|c|}{$\begin{array}{c}\text { Dependent Variable: } \\
\text { Plaintiff Represent. Attorney or Law Firm }\end{array}$} & \multicolumn{2}{|c|}{$\begin{array}{c}\text { Dependent Variable: } \\
\text { Defendant Represent. Attorney or Law Firm }\end{array}$} \\
\hline & Coefficient & Standard Error & Coefficient & Standard Error \\
\hline \multicolumn{5}{|l|}{ Instruments for Parties' Legal Representation } \\
\hline Plaintiff Avg. No. of Employees (in 100s) & $-0.026 \ddagger$ & $(0.024)$ & 0.028 & $(0.024)$ \\
\hline Defendant Avg. No. of Employees (in 100s) & -0.010 & $(0.008)$ & $-0.045^{* *}$ & $(0.018)$ \\
\hline \multicolumn{5}{|l|}{ Parties' Legal Form } \\
\hline Plaintiff Legal Entity in Public Interest & $1.082 * *$ & $(0.480)$ & $3.703 * * *$ & (1.316) \\
\hline Plaintiff Company & 0.205 & $(0.273)$ & 0.167 & $(0.718)$ \\
\hline Plaintiff Sole Trader Enterprise & 0.147 & $(0.295)$ & 0.125 & $(0.806)$ \\
\hline Defendant Company & $1.698 * * *$ & $(0.281)$ & -0.013 & $(0.932)$ \\
\hline Defendant Sole Trader Enterprise & $1.745^{* * *}$ & $(0.301)$ & 0.253 & $(0.921)$ \\
\hline \multicolumn{5}{|l|}{ Parties' Size and Profitability } \\
\hline Plaintiff Assets (in EUR 100 million) & 0.016 & $(0.021)$ & -0.020 & $(0.025)$ \\
\hline Defendant Assets (in EUR 100 million) & 0.003 & $(0.004)$ & $0.021 * *$ & $(0.010)$ \\
\hline Plaintiff ROA & 0.156 & $(0.158)$ & 0.439 & $(0.540)$ \\
\hline Defendant ROA & $-0.978 * * *$ & $(0.281)$ & -0.186 & $(0.818)$ \\
\hline \multicolumn{5}{|l|}{ Case Characteristics } \\
\hline Stakes (in EUR 100,000) & 0.006 & $(0.015)$ & $0.040^{*}$ & $(0.022)$ \\
\hline Court Expert & -0.030 & $(0.132)$ & 0.265 & $(0.229)$ \\
\hline \multicolumn{5}{|l|}{ Fixed Effects } \\
\hline Court FEs & \multicolumn{2}{|c|}{ Yes } & \multicolumn{2}{|c|}{ Yes } \\
\hline Plaintiff Industry FEs & \multicolumn{2}{|c|}{ Yes } & \multicolumn{2}{|c|}{ Yes } \\
\hline Defendant Industry FEs & \multicolumn{2}{|c|}{ Yes } & \multicolumn{2}{|c|}{ Yes } \\
\hline Filing Year FEs & \multicolumn{2}{|c|}{ Yes } & \multicolumn{2}{|c|}{ Yes } \\
\hline Disposition Year FEs & \multicolumn{2}{|c|}{ Yes } & \multicolumn{2}{|c|}{ Yes } \\
\hline \multicolumn{5}{|l|}{ Inverse Mills Ratio } \\
\hline Lambda-hat & 0.208 & $(0.150)$ & 0.142 & $(0.337)$ \\
\hline R-squared & \multicolumn{2}{|c|}{0.8946} & \multicolumn{2}{|c|}{0.7084} \\
\hline No. Obs. & \multicolumn{2}{|c|}{90} & \multicolumn{2}{|c|}{90} \\
\hline
\end{tabular}

Notes: Results of first-stage regressions for the 2SLS estimates in column (2) of Table 6. Reported standard errors are heteroskedasticity-robust. *, **, and *** indicate significance at the $10 \%, 5 \%$, and $1 \%$ levels, respectively. $\neq: p$-value for a one-sided test equals 0.136 . 